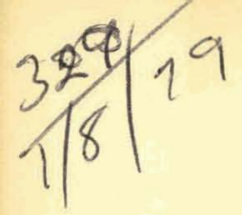

E'ERGY

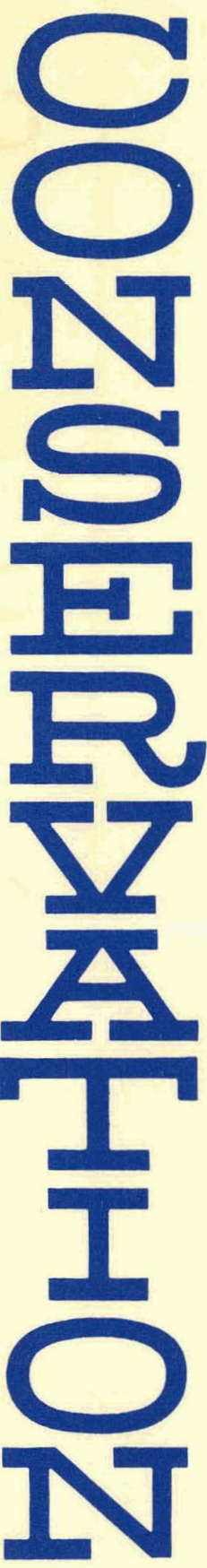

ORNL/SUB-78/55463/1

Dist, Category UC-95D

IMPROVING THE ENERGY EFFECTIVENESS

OF DOMESTIC REFRIGERATORS BY THE

APPLICATION OF REFRIGERANT MIXTURES

\author{
Prepared by \\ W. F. STOECKER
}

Professor of Mechanical Engineering

University of Illinois at Urbana-Champaign

Urbana, IL 61801

\author{
Oak Ridge National Laboratory \\ Operated by \\ UNION CARBIDE CORPORATION
}

September 8, 1978

U. S. DEPARTMENT OF ENERGY

Division of Buildings and Community Systems 


\section{DISCLAIMER}

This report was prepared as an account of work sponsored by an agency of the United States Government. Neither the United States Government nor any agency Thereof, nor any of their employees, makes any warranty, express or implied, or assumes any legal liability or responsibility for the accuracy, completeness, or usefulness of any information, apparatus, product, or process disclosed, or represents that its use would not infringe privately owned rights. Reference herein to any specific commercial product, process, or service by trade name, trademark, manufacturer, or otherwise does not necessarily constitute or imply its endorsement, recommendation, or favoring by the United States Government or any agency thereof. The views and opinions of authors expressed herein do not necessarily state or reflect those of the United States Government or any agency thereof. 


\section{DISCLAIMER}

Portions of this document may be illegible in electronic image products. Images are produced from the best available original document. 
Printed in the United States of America. Available from National Technical Information Service

U.S. Department of Commerce

5285 Port Royal Road, Springfield, Virginia 22161

Price: Printed Copy $\$ 6.00$; Microfiche $\$ 3.00$

This report was prepared as an account of work sponsored by the United States Government. Neither the United States nor any of its employees, nor any of its contractors, subcontractors, or their employees, makes any warranty, express or implied, or assumes any legal liability or responsibility for the accuracy, completeness or usefulness of any information, apparatus, product or process disclosed, or represents that its use would not infringe privately owned rights. 
ORNL/Sub-78/55463/1

Dist. Category UC-95d

\title{
IMPROVING THE ENERGY EFFECTIVENESS \\ OF DOMESTIC REFRIGERATORS BY THE \\ APPLICATION OF MIXED REFRIGERANTS
}

FINAL REPURT

SEPTEMBER 8, 1978

Date Published: January 1979

\author{
UNIVERSITY OF ILLINOIS AT URBANA-CHAMPAIGN \\ Urbana, Illinois 61801 \\ Principal Investigator: \\ W. F. Stoecker \\ Professor of Mechanical Engineering
}

Prepared under P. O. 19x-55463V for the

OAK RIDGE NATIONAL LABORATORY

Oak Ridge, Tennessee 37830

operated by

UNION CARBIDE CORPORATION

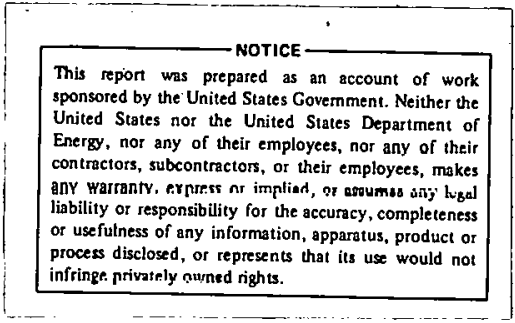

for the

UNITED STATES DEPARTMENT OF ENERGY

Contract No. W-7405-eng-26 
THIS PAGE

\section{WAS INTENTIONALLY LEFT BLANK}


A critical review of U.S, and foreign literature on the use of a mlxture of refrigerants rather than a single one in a refrigeration unit indicates that energy can be conserved in properly arranged systems. An independent analytical study performed under the current contract using a 50 percent mixture of $R-12$ and $R-114$ in a two-evaporator refrigerator typical of domestic refrigerators showed an energy saving of 12 percent. The cycle explored was a non-optimized one, so greater energy savings are theoretically possible.

The application of refrigerant mixtures to domestic refrigerators would not be a panacea, but would require a redesign of the refrigeration circuit and a resizing of the compressor. There would be a number of problems to be explored and solved before a successful application could be achieved, but the prospects look favorable at this time.

One of the most useful next steps would be to continue to expand the knowledge base on refrigerant mixtures that would be made available to the manufacturers of refrigerators. 
THIS PAGE

\section{WAS INTENTIONALLY LEFT BLANK}


SCOPE OF WORK

In the proposal from the University of Illinois dated

19 May 1978 to the Department of Energy, we proposed the following:

1. Make a critical review of the refrigerant-mixture literature,

2. Establish the necessary thermodynamic properties for a subsequent analysis,

3. Conduct cycle analyses to prove or disprove potential energy savings, and

4. Based on Tasks 1 and 3 recommend either continuation or termination of future consideration of refrigerant mixtures.

In the report that follows, we have responded to each of

these proposed tasks in the following manner:

1. Reviewed all papers listed in the bibliography starting on page 56, presented a synopsis of each of these papers in Appendix A starting on page 61, and incorporated the findings from these papers at appropriate points throughout the body of the report.

2. Presented a review of thermodynamic properties of binary mixtures and developed equations for one mixture combination, $\mathrm{R}-12 / \mathrm{R}-114$ which was used as the sample mixture.

3. Chapter 3, 4, and 5 deseribe the predictions of energy effectiveness of four different cycles utilizing techniques of steady-state system simulation to isolate the influences of changes in concentrations of the mixture used.

4. Based both on the analyses in this report and the experience of other regearchers, there is a potential for energy conservation, and some recommended next steps are proposed in Chapter 6 . 


\section{THIS PAGE}

\section{WAS INTENTIONALLY \\ LEFT BLANK}


TABLE OF CONTENTS

Abstract....................... $i i_{i}$

Scope of Work ................

1. How Refrigerant Mixtures Perform . . . . . . . 1

2. Thermodynamic Properties of Refrigerant Mixtures 13

3. Single Train System with Single Evaporator . . . 21

4. Single-Train, Two-Evaporator System ...... 39

5. Separating Cycle in a Two-Evaporator Refrigerator 48

6. Conclusions and Recommendations ....... 53

7. Bibliography ............ 56

Appendix A. Synopsis of Literature ........ 61

Appendix B. Equations Subroutine for Computer Program

in Chapter 4 .......... 65 


\section{HOW REFRIGERANT MIXTURES PERFORM}

1-1. Application of mixtures in a refrigeration system. Although the attempts to use a mixture of substances as the working medium in refrigeration units dates back at least to 1888 (Pictet), the early attempts did not fully appreciate the requirements for the mixtures that would result in cycle improvements. Carr ${ }^{8}$ in 1949 wrote one of the good early papers that was sound from a thermodynamic standpoint to show the possibility of conserving power by taking advantage of the change in temperature during evaporation of a mixture. Carr recognized that the potential existed when the refrigeration duty consisted of cooling a fluid stream through a large change in temperature. Carr's study was purely analytical, and he used a mixture of hydrocarbons as the working substance since the properties of hydrocarbon mixtures were more well-known at that time in comparison to mixtures of halocarbons.

Little research is reported in the 1950's, but various workers in the 1960's and so far in the 1970's have explored the use of refrigerant mixtures primarily for two objectives:

(1) achieving a low evaporator temperature with a moderate pressure ratio during single-stage compression, and (2) conserving energy when the refrigeration duty consists of cooling a fluid stream through a large temperature range.

The refrigeration duty in a two-evaporator refrigerator might be considered the counterpart of cooling a fluid stream through a large temperature range since some refrigeration is required at 
a moderate temperature and additional refrigeration at a low temperature. In the proposal that resulted in this current study of refrigerant mixtures, one of the tasks proposed was to critically review the literature and the thermodynamic principles to be certain that at least theoretical possibilities exist for conserving energy. A companion task is to provide an explanation of why a refrigeration system with a mixture of refrigerants might have superior energy characteristics. This chapter attempts, then, to explain the behavior of a system using a mixture and to illustrate the validity of its potential for saving energy. Achieving this energy conservation imposes some other requirements (perhaps larger heat-transfer areas), and the reasons for these requirements will be pointed out.

Any evaluation will be facilitated by a basic understanding of how a binary mixture performs in a refrigeration system, so the next several sections review the properties of these mixtures. 1-2. Binary solutions. A binary solution consists of two separate substances which are capable of forming a liquid solution together. If a vessel, as in Fig. 1-1, contains a binary solution

$\underbrace{\text { Vapor }}_{\begin{array}{c}\text { Iiquid } \\ \text { Substances } A \text { and } B\end{array}}$

Fig. 1-1. A binary sulution.

of Substances $A$ and $B$, both $A$ and $B$ exist in both the Iiquid and vapor phases. In general the fraction 
of Substance $A$ in the vapor is different from the fraction of Substance $A$ in the liquid. There are cases where the composition of the vapor is the same as that of the liquid, and such a solution is called "azeotropic." Azeotropic solutions are very important in refrigeration practice (the 500-series, including R-502), but the azeotropes are not the subject of this study. An azeotropic mixture behaves as a separate pure substance and mixtures that are definitely non-azeotropic are the subject of this current study.

\section{1-3. Temperature-concentration-pressure characteristics}

of binary mixtures. Figure $1-2$ shows for a given pressure the

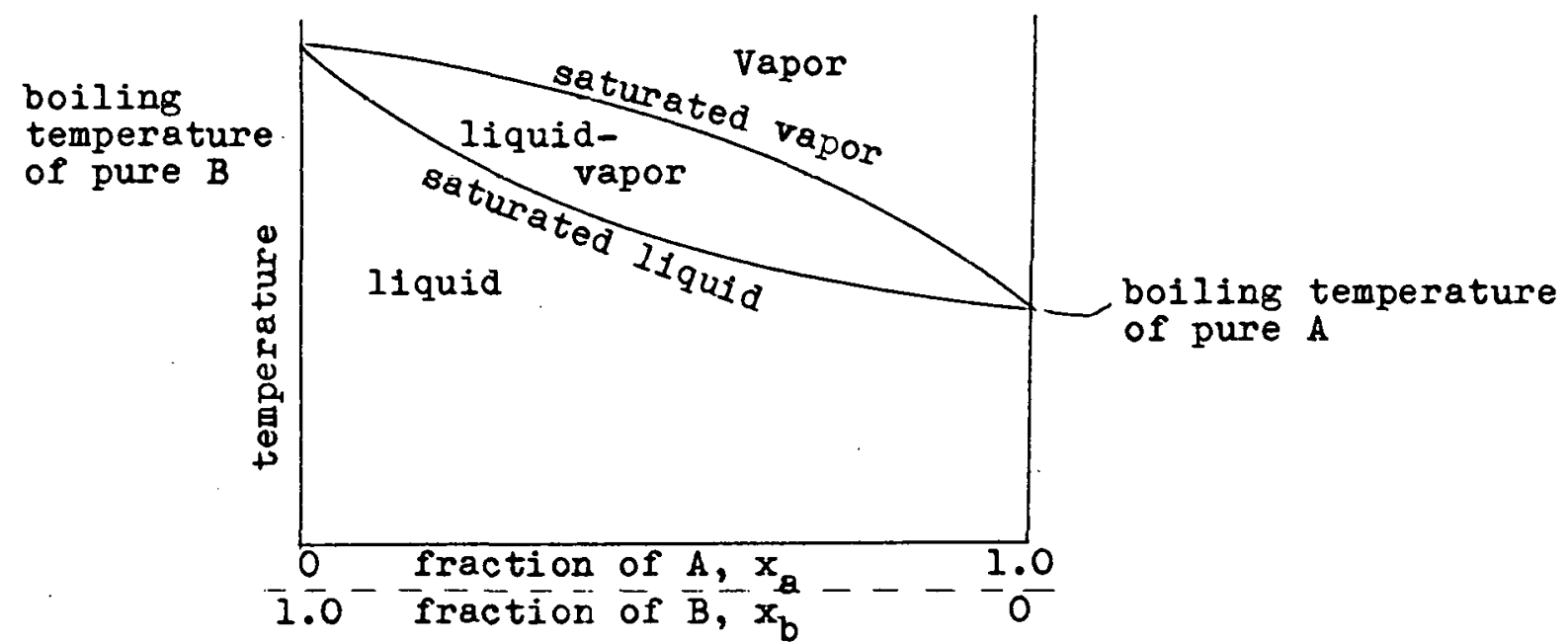

Fig. 1-2. Temperature-concentration diagram of a binary

solution at a constant pressure.

temperature-concentration (t-x) graph of a binary mixture. The abscissa is the "fraction of material $A$ " and the complementary scale is the "fraction of material B." There are three distinct regions displayed in Fig. 1-2: the liquid region, the liquidvapor region, and the vapor region. These regions are separated by the saturated liquid and saturated vapor lines. The saturated 


\section{$-4-$}

liquid line is sometimes called the "bubble-point line," and the saturated vapor line is sometimes called the "dewpoint line." On the saturated liquid line the mixture is 100 percent liquid and below the line the liquid is subcooled. On the saturated vapor line the mixture is 100 percent vapor and above the line the vapor is superheated. The "dewpoint line" refers to the boundary at which saturated liquid begins to form if superheated vapor is cooled at constant pressure. The "bubble-point line" is the boundary at which saturated vapor begins to form if subcooled liquid is heated at constant pressure.

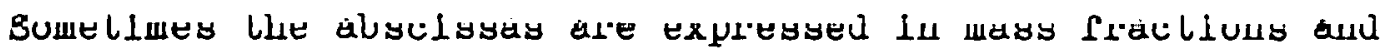
sometimes in mol fractions. The mol fraction of A, for example, is

$$
\begin{aligned}
& \text { mol fraction of } A=\frac{\operatorname{mol} \text { of } A}{\text { mol of } A+\text { mol of } \bar{B}} \\
&=(\text { mass of } A, k g) /\left(\mathrm{MW}_{A}\right) \\
&\text { (mass of } \mathrm{A}, \mathrm{kg}) /\left(\mathrm{MW}_{\mathrm{A}}\right)+(\text { mass of } \mathrm{B}, \mathrm{kg}) /\left(\mathrm{MW}_{B}\right)
\end{aligned}
$$

where $W_{A}$ and $M W_{B}$ are the molecular weights of substance $A$ and B, respectively.

The bulging curves in Fig. 1-2 are typical of an ideal binary mixture, and there are many combinations of substances that behave ideally. On the other hand, many substances combine in a non-ideal way, and a $t-x$ curve as shown in Fig. 1-3 may result. The saturated 1 iquid and saturated vapor curves are close together and there is only a small temperature difference between them. A binary mixture of $R-12$ and $R-22$ behaves in this fashion. At one point the curves in Fig. 1-3 touch, and the significance of this point is that it marks an azeotropic mixture (R-501). The characteristics shown in Fig. 1-3 are not the most desired ones 


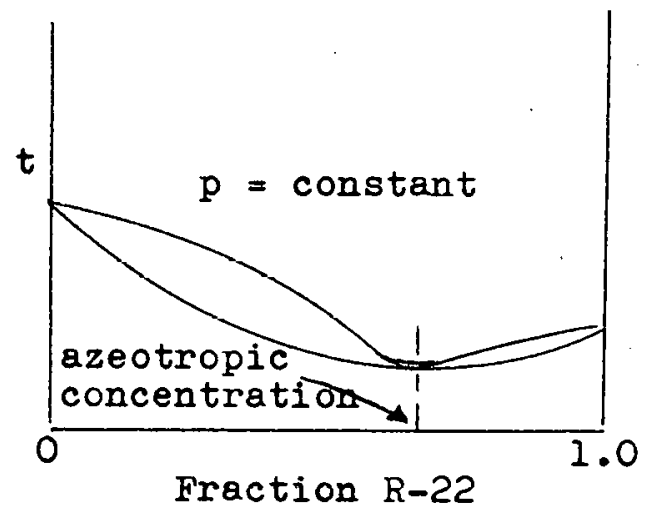

Fig. 1-3. Non-ideal binary mixture: R-12/R-22.

for the combination that will be sought for the two-evaporator domestic refrigerator.

1-4. Effect of pressure. The curves shown in Fig. 1-2 are applicable to a given pressure. There is a different set of curves for each pressure, and curves describe higher temperatures as the pressure increases, as shown in Fig. 1-4. For ideal binary

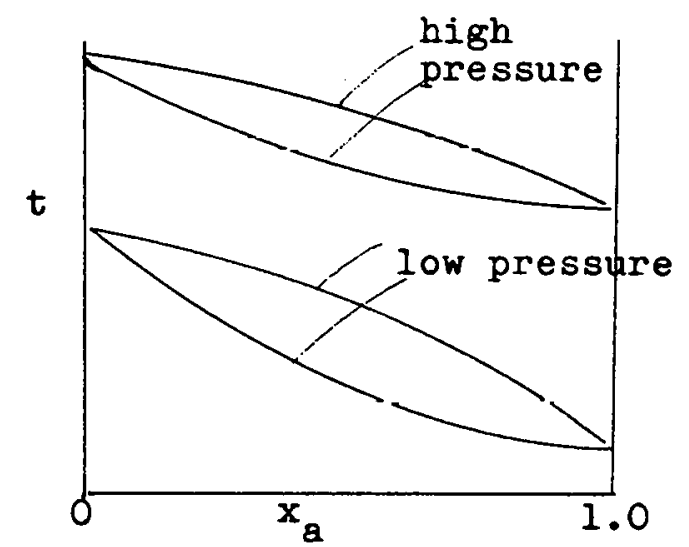

Fig. 1-4. Effect of pressure on t-x diagrams.

solutions the temperature spread between the saturated liquid and vapor lines narrows as the pressure increases.

1-5. Evaporation of a binary mixture. A special property possessed by binary mixtures that has potential application to the 
utilization of mixtures of refrigerants is that the temperature changes during a constant-pressure evaporation. This behavior is in contrast to a pure substance that boils at constant temperature if the pressure remains constant. If an evaporator consists of a single tube, as shown in Fig. 1-5, and subcooled liquid

\begin{tabular}{|c|c|c|c|c|}
\hline 1 & 2 & 3 & 4 & 5 \\
\hline $\begin{array}{l}\text { subcooled } \\
\text { liquid }\end{array}$ & $\begin{array}{l}\text { boiling } \\
\text { begins }\end{array}$ & $\bullet$ & $\frac{\text { all }}{\text { vaporized }}$ & 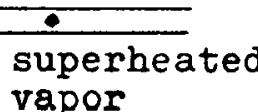 \\
\hline
\end{tabular}

Fig. 1-5. Evaporation of a binary mixture. enters at statepoint 1 in Fig. 1-6, the solution is heated at constant concentration until point 2 is reached at which position

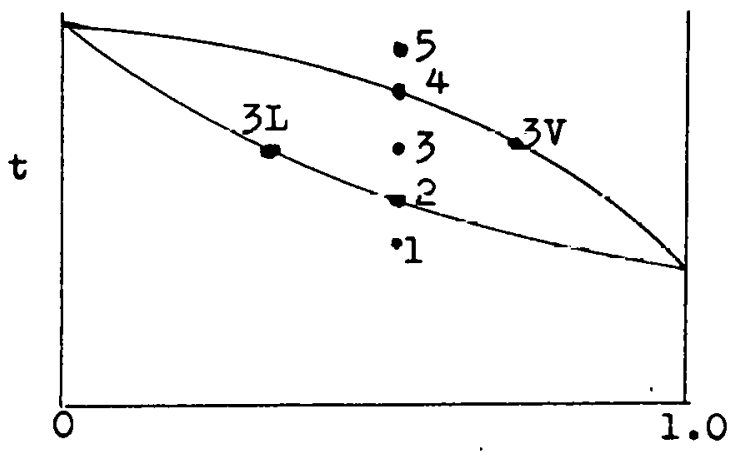

Fig. 1-6. Statepoints during evaporation.

the solution begins to vaporize. As the mixture proceeas along the evaporator, progressively more ilquid evaporates, and even though the combined state is indicated by point 3 , the fluid consists of a mixture of liquid at $3 \mathrm{I}$ and vapor at $3 \mathrm{~V}$. The fraction of liquid at point 3 is represented by the equation

$$
\text { fraction in 11quid form }=\frac{x_{3 V}-x_{3}}{x_{3 V}-\bar{x}_{3 L}}
$$


The temperature of the solution progressively increases in both the subcooled liquid and the superheater vapor regions, just as for a pure substance, but the unique feature of the binary solution is that the temperature changes during the boiling process also. 1-6. Ideal refrigeration cycle using binary mixtures. To lead toward a comparison of the performance of a refrigeration system that utilizes a mixture as the working substance with the performance of a single-refrigerant system, an ideal system will be proposed with the equipment shown in Fig. 1-7. The corresponding t-x-p diagram is shown in Fig. $1-8$ and the temperatureentropy diagram in Fig. 1-9.

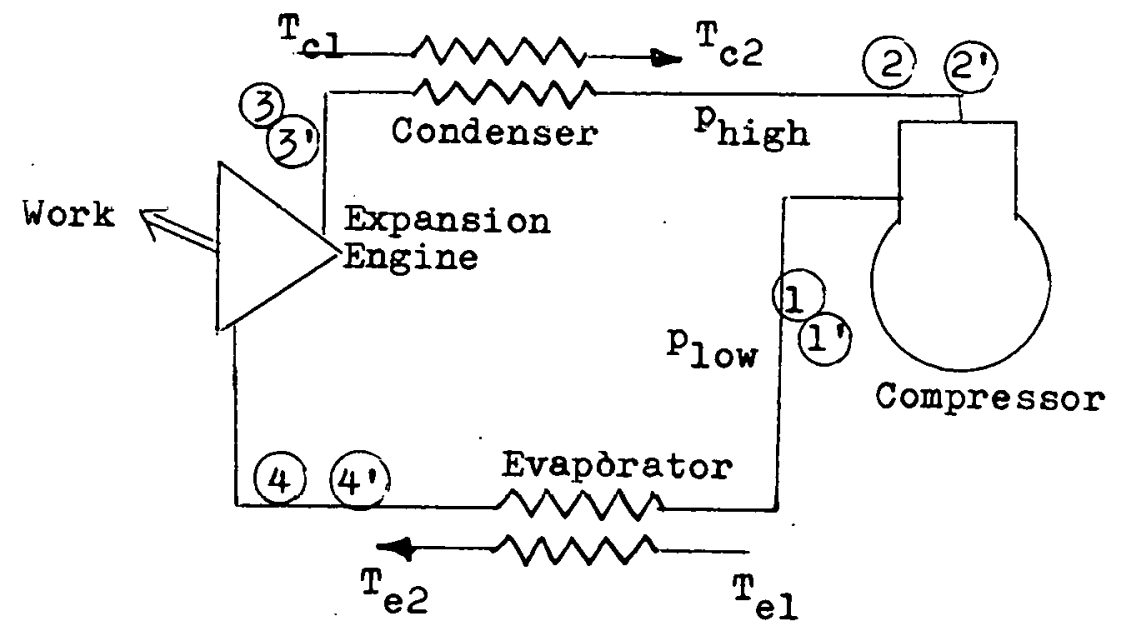

Fig. 1-7. Refrigeration system.

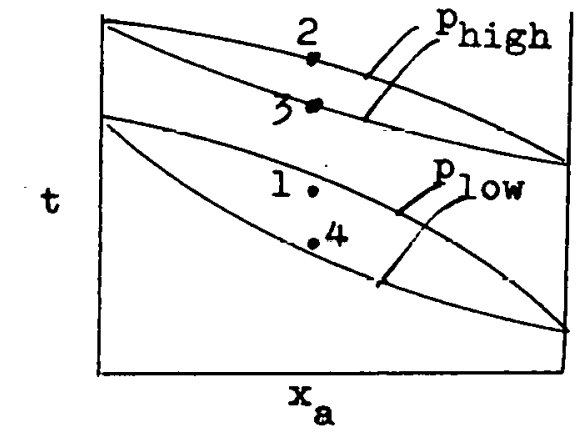

Fig. 1-8. Temperature-concentration-pressure diagram. 


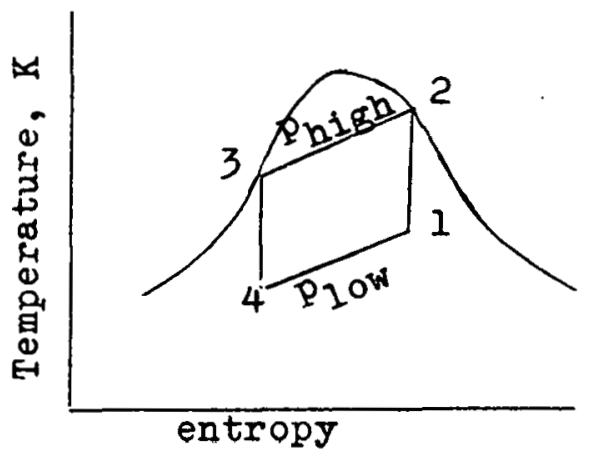

Fig. 1-9. Temperature-entropy diagram of ideal cycle using a refrigerant mixture.

The processes consist of the following:

1. a reversible and adiabatic compression at constant entropy from point 1 to 2 ,

2. constant pressure condensation from 2 to 3 ,

3. reversible and adiabatic expansion where the work is recovered and used, 3-4, and

4. constant pressure evaporation for the refrigeration pronesse from 4 to 1 .

Point 2 is arbitrarily placed on the saturated vapor Iine and point 3 on the saturated liquid line which corresponds to the usual convention of showing a Carnot refrigeration cycle in classical thermodyaamics, as in Fig. 1-10. In order to arrive at point 2

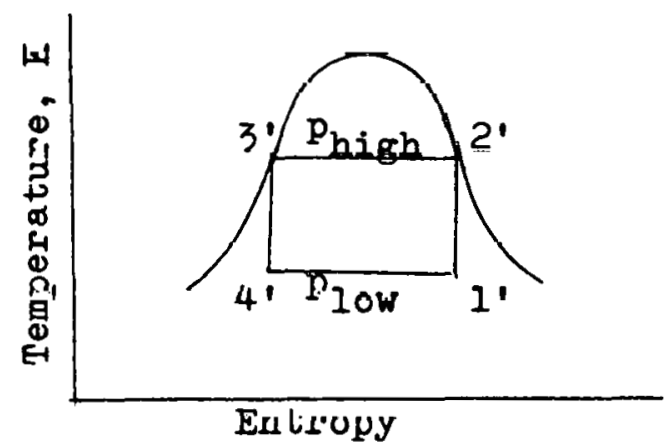

F1g. 1-10. Temperature-entropy diagraw of ideal refrigeration oycle using a single substance. 
following the isentropic compression it is necessary to begin the compression at point 1 with a small fraction of liquid present, just as is true in the single-substance cycle in Fig. 1-10. Similarly, when the expansion takes place through the engine the state of the refrigerant leaving the engine will be in the mixture region--both at points 4 and $4^{\prime}$.

1-7. Using the T-s diagrams to compare efficiencies. The key to determining whether Fig. 1-9 or Fig. 1-10 displays a cycle of highest COP depends upon the comparative temperatures occurring during the high pressure and during the low pressure condensation and evaporation processes. This decision in turn depends upon the temperatures of the condenser cooling medium and the temperature of the fluid being cooled. The condenser is assumed to reject heat to a fluid changing temperature, and the evaporator is assumed to receive heat from a fluid changing temperature. The terminal temperatures of these two fluids are indicated in Fig. 1-7 and are shown on the composite T-s diagram in Fig. 1-11. The

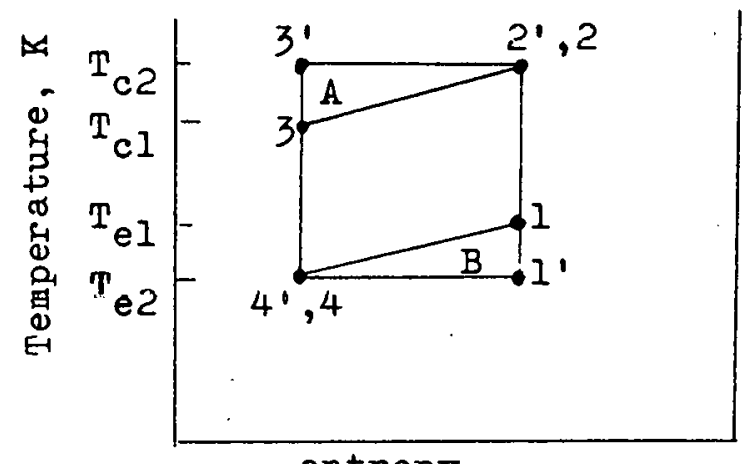

entropy

Fig. 1-11. Composite temperature-entropy diagram. condenser and evaporator fluids are configured in counterflow to the refrigerant in their respective heat exchangers. In an evaporator or condenser where a single refrigerant boils 
or condenses, and where there is no subcooling or superheating or subcooling, it is immaterial whether counterflow, parallelflow, or cross-flow is provided. For the effective use of the mixed-refrigerant cycle it is crucial to provide counterflow. Figure $1-11$ shows that in order to cool the evaporator fluid to $\mathrm{T}_{\mathrm{e} 2}$ in the single refrigerant system it is necessary that the evaporating temperature be equal or below $\mathrm{T}_{e 2}$. In order to reject heat to the cooling fluid at $T_{c 2}$ the condensing temperature in the single-refrigerant system must be $\mathrm{T}_{\mathrm{c} 2}$ or above.

For the mixed refrigerant system, on the other hand, the requiromontc aro that $\mathrm{T}_{1} \leqslant \mathrm{~T}_{\mathrm{el}}, \quad \mathrm{T}_{4} \leqslant \mathrm{~T}_{\mathrm{e} 2}, \quad \mathrm{~T}_{2} \geqslant \mathrm{~T}_{\mathrm{c} 2}$, and $\mathrm{T}_{3} \geqslant \mathrm{~T}_{\mathrm{cl}} \cdot$ The latter requirements are less restrictive from a thermodynamic standpoint than those for the single-refrigerant system. Because the processes in both refrigeration cycles are reversible, areas on the T-s diagram represent energy quantities. Designate the triangular areas as $A$ and $B$, as shown in Fig. 1-11, and for the single-refrigerant system designate the refrigeration energy as $Q_{s}$ and the net work to operate the cycle as $W_{s} \cdot$ The COP's of the two eycles are

$$
\begin{aligned}
& \text { COP of single-refrigerant system }=\frac{Q_{B}}{W_{B}} \\
& \text { COP of mixed-refrigerant system }=\frac{Q_{S}+B}{W_{S}-A-B}
\end{aligned}
$$

The COP of the mixed-refrigerant system is thus higher than that of the single-refrigerant system.

The COP of the mixed-refrigerant system will be higher than that of the single-refrigerant system only if one or both the fluid being cooled in the evaporator or the fluid being 
heated in the condenser change temperature. A refrigeration system operating between a constant-temperature source and a constant-temperature sink would be more efficient if a single refrigerant were used. It is expected that in the conversion from ideal to real systems that the magnitude of temperature change must be appreciable in order to achleve a higher COP with the mixed-refrigerant system.

1-8. Comparative heat-transfer areas. The improvement in energy effectiveness provided by the mixed-refrigerant system occurs by virtue of reducing the irreversibilities in the external heat-transfer process, but at the expense of mean temperature difference between the refrigerant and the external fluid. As the mean temperature difference is reduced, the heat transfer area would have to be increased correspondingly. To make a fair comparison between the two systems, the same mean temperature difference must be provided. As Fig. 1-12 shows for an evaporator the lowest temperature of the mixed refrigerant must be

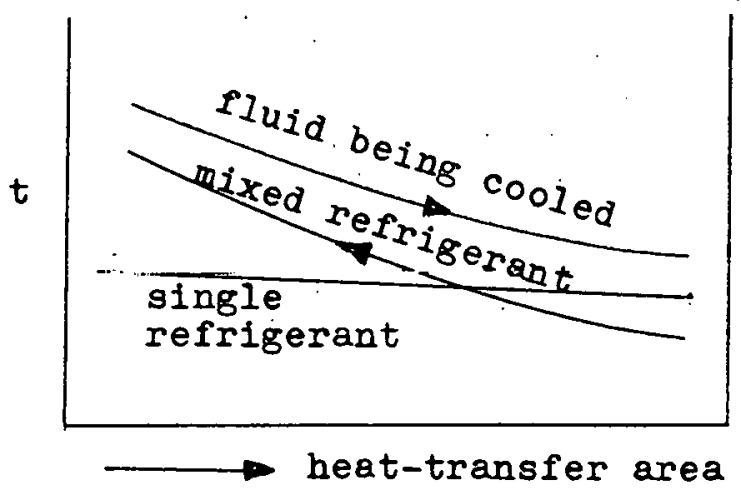

Fig. 1-12. Maintaining same mean-temperature differences for both systems. lower than the single refrigerant evaporator temperature in 
contrast to that shown in Fig. 1-11 in order to maintain the same mean-temperature difference for both systems.

\section{1-9. Potential application to two-evaporator domestic}

refrigerator. Since cooling the evaporator fluid through a large temperature range is a crucial property of those applications where the mixed-refrigerant system would seem to have advantages, it is appropriate to assess whether the two-evaporator domestic refrigerator meets that criteria. The cooling ranges of the air through the evaporators are not expected to be large, as Fig. 1-13 shows,

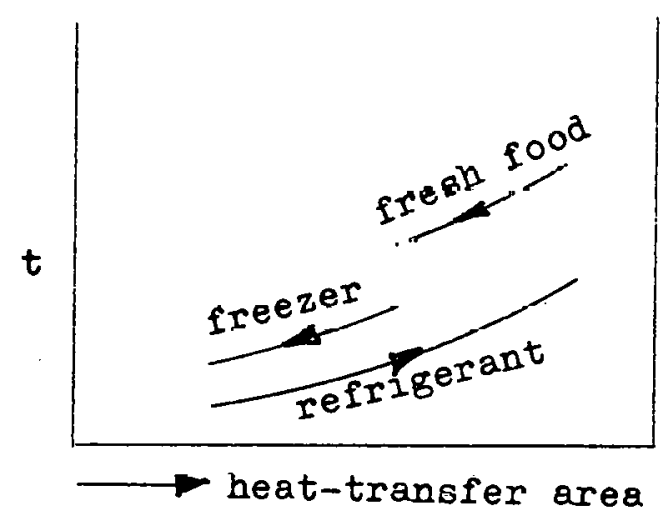

F18: 1-13. Temperature changes in a two-evaporator refrigerator. but a portion of the refrigeration load occurs at a relatively high temperature such that the tail of the evaporating process of the refrigerant mixture will be of sufficiently low temperature to perform this refrigeration. 


\section{THERMODYNAMIC PROPERTIES OF REFRIGERANT MIXTURES}

2-1. Thermodynamic properties needed for analyses. In order to perform cycle analyses of refrigerant mixtures in refrigerators the following relationships are needed: (1) p-x-t equations at saturated conditions, (2) $h-x-t$ at saturated conditions for both liquid and vapor, and (3) relationships to compute the change in enthalpy during an isentropic compression,

where $p=$ pressure, $\mathrm{kPa}$ (psia)

$$
\begin{aligned}
& \mathbf{x}=\text { fraction of one constituent on a mass basis } \\
& t=\text { temperature, }{ }^{\circ} \mathrm{C}\left({ }^{\circ} \mathrm{F}\right) \\
& \mathrm{h}=\text { enthalpy, } \mathrm{kJ} / \mathrm{kg}(\mathrm{Btu} / \mathrm{lb})
\end{aligned}
$$

2-2. Conversion to British units. Most of the calculations in this report are performed in SI units, but in most cases the key values are presented in British units as well. Should there be a

\begin{tabular}{|c|c|c|c|}
\hline to convert & in & to & operation \\
\hline pressure & $\mathrm{kPa}$ & psia & multiply by 0.1450 \\
\hline temperature & ${ }^{\circ} \mathrm{C}$ & $\mathrm{F}$ & multiply by 1.8 , add 32.0 \\
\hline $\begin{array}{l}\text { enthalpy (in SI the } \\
\text { base is } 200 \mathrm{~kJ} / \mathrm{kg} \text { for } \\
\text { saturated liquid at } \\
0^{\circ} \mathrm{C} \text { ) }\end{array}$ & $\mathrm{kJ} / \mathrm{kg}$ & Btu/lb & $\begin{array}{l}\text { subtract } 200 \text { from } \mathrm{h} \text { in } \\
\mathrm{kJ} / \mathrm{kg} \text {, then multiply by } \\
0.4299 \text {. Finally add } \mathrm{h}_{\mathrm{f}} \\
\text { at } 32^{\circ} \mathrm{F} \text { from Btu/lb } \\
\text { table. }\end{array}$ \\
\hline heat transfer rate & $\mathrm{kW}$ & Btu/hr & multiply by 3412 . \\
\hline mass flow rate & $\mathrm{kg} / \mathrm{s}$ & $\mathrm{lb} / \mathrm{hr}$ & multiply by 7937. \\
\hline
\end{tabular}
need for conversion of the properties or energy flow rates, the following operation may be performed: 
2-3. Choice of refrigerant mixture: $\mathrm{R}-12 / \mathrm{R}-114$. In order to compute values in the cycle analyses of Chapters 3 through 5 , some certain combination of two refrigerants had to be chosen. That choice was $R-12 / R-114$. This combination is not necessarily a recommendation that the mixture is the most advantageous, but it may be a good choice. Only further investigation will confirm or refute the desirability of this combination. The following reasoning favored the temporary selection of the R-12/R-114 mixture.

Refrigerant-12 would seem to be a logical choice for the base refrigerant, because it is the commonly-used refrigerant in domestic refrigerators at the prosent time. Thio refrigerant remains miscible with oil at the low temperatures experienced in ref'rigerators. Also comparisons with the performance of conventional refrigerators would be more nearly achieved.

Probably the most common refrigerants in residential applications are $R-12$ and $R-22$, so that mixture should be a candidate. The reason for not choosing this combination is that there is not $a$ wide spread between the temperatures on the $t-x-p$ diagram (as shown in Fig. 1-3. In fact, such references as Kandlikar ${ }^{17}$, Kriebel ${ }^{23}$, Loeffler ${ }^{30}$, Neilson ${ }^{36}$, and Spauschus ${ }^{40}$, point out the possibility of forming an azeotrope with this combination.

Loreng 31 urged ehoosing refrigerante with widely different boiling temperatures at a given pressure in order to achieve a large maximum $\Delta t$, as illustrated in Fig. 2-l. Lorenz found from a study of 30 mixlures that

$$
\Delta t_{\max }=0.04\left(\Delta t^{\prime}\right)^{1.616}
$$

so the other refrigerant to be mixed with $\mathrm{R}-12$ should ideally have a boiling point much higher or much lower than R-12. 


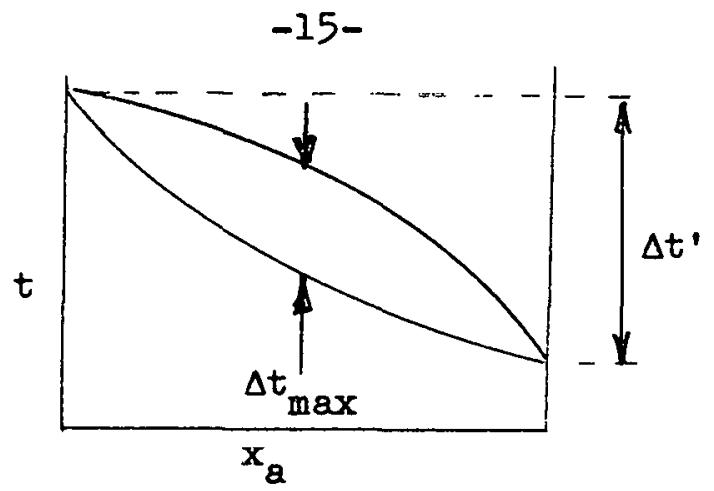

Fig. 2-1. Large difference in boiling points needed. Among the lower-boiling temperature refrigerants would be included R-13 which has been studied by Agarwal', Arora ${ }^{3}$, Kazacki ${ }^{18}$, Makorov ${ }^{34}$, and Tschaikovsky 42 and 44 . The R-13 combination was not chosen because of its low critical temperature of $28.8^{\circ} \mathrm{C}(83.9 \mathrm{~F})$. This concern may not truly be sufficient cause to permanently reject. $R-13$, and $R-13$ does have the advantage of being more dense than R-12 which is favorable from the standpoint of the required compressor displacement rate.

Among the high bolling refrigerants $\mathrm{R}-11$ is one to be considered, as has been done by Bondarev ${ }^{6}$ and Lorenz ${ }^{32}$. One reason for ruling out $R-12 / R-11$ is that the standard COP of R-11 (page 15.7, ASHRAE Handbook of Fundamentals, 1977) is 5.03 in comparison to that of $\mathrm{R}-12$ which is 4.70 at the evaporating temperature of $-15^{\circ} \mathrm{C}$ (5 F) and condensing temperature of $30^{\circ} \mathrm{C}(86 \mathrm{~F})$. Since this study investigates potential improvements attributable to mixtures, improvements in COP resulting from gradual substitution of a highCOP refrigerant were eliminated.

Finally the combination of $\mathrm{R}-12$ and $\mathrm{R}-114$ was chosen because (1) the COP's at standard conditions are about the same--4.70 for $R-12$ and 4.67 for $R-114$, and (2) the combination behaves as an 1deal mixture. Eiseman ${ }^{11}$ states that mixtures of two polar 
refrigerants, such as $\mathrm{R}-22$ and $\mathrm{R}-21$ or two non-polar refrigerants, such as $R-12$ and $R-114$ behave as ideal mixtures. Kraus $^{24}$ also supports this contention. The advantage of using an ideal mixture for the objectives of this study is that the calculated properties will be more accurate. The mixture was used by Arora ${ }^{3}$ who stated that adding $\mathrm{R}-114$ to $\mathrm{R}-12$ increases the COP, but decreases the capacity (with a given compressor displacement rate).

The important criterion in the choice of mixtures for this study is to find one which will show possibilities of energy savings. If one such mixture can be found, it is possible that there way be other even more-favorable mixtures.

2-4. Developing $t-x-p$ relationships. The tools for developing the saturated liquid and saturated vapor data (such as in Fig. 1-2) are (1) saturation pressure vs temperature relationships of the two substances, (2) Raoult's law, and (3) Dalton's law. 2-5. Saturation pressure-temperature relationships. A simple and fairly accurate form to relate the saturation pressure to the temperature is

$$
\ln (\mathrm{p})=\mathrm{C}+\mathrm{D} / \mathrm{T}
$$

where $C$ and $D$ are constants

p = saturation pressure

I absolute lemperalure

For the two refrigerants chosen, the equations are

$$
\begin{array}{ll}
\text { R-12: } & \ln (\mathrm{p})=14.861-2498.3 / \mathrm{T} \\
\mathrm{R}-11 \text { 14: } & \ln (\mathrm{p})=15.40^{\prime} /-2993.2 / \mathrm{T} \\
\text { where } & \mathrm{p}=\text { saturation pressure, } \mathrm{kPQ} \\
& \mathrm{T}=\text { temperature, } \mathrm{K}
\end{array}
$$

The comparison of the pressure values calculated from Eqs. 2-2 and 2-3 
with data from the 1977 ASHRAE Handbook of Fund. appears in Table 2-1.

Table 2-1. Comparison of tabular values with Eqs. 2-2 and 2-3 .

\begin{tabular}{|c|c|c|c|c|}
\hline \multirow{2}{*}{ Refrigerant } & \multirow{2}{*}{ Temperature } & \multicolumn{2}{|c|}{ Saturation Pressure } & \multirow{2}{*}{ Percent Error } \\
\hline & & Table & Equation & \\
\hline \multirow[t]{3}{*}{$R-12$} & $-50^{\circ} \mathrm{C}$ & $39.15 \mathrm{kPa}$ & $39.07 \mathrm{kPa}$ & -0.20 \\
\hline & 0 & 308.61 & 303.31 & -1.72 \\
\hline & 50 & 1219.30 & 1248.77 & 2.42 \\
\hline \multirow[t]{3}{*}{$R-114$} & -50 & 7.23 & 7.34 & 1.60 \\
\hline & 0 & 87.53 & 85.53 & -2.28 \\
\hline & 50 & 445.41 & 466.11 & 4.65 \\
\hline
\end{tabular}

2-6. Raoult's law. Raoult's law declares that the vapor pressure of one component in a mixture, $\mathrm{P}_{\mathrm{a}}$

$$
P_{a}=\left(\nabla_{a, L}\right)\left(p_{a}\right)
$$

where $P_{Q}=$ vapor pressure of substance $A$ in the mixture, $\mathrm{kPa}$ $\nabla_{Q, L}=$ mol fraction of substance $A$ in the liquid, dimensionless $p_{a}=$ saturation pressure of pure $A$ at the existing temperature, $\mathrm{kPa}$

The molecular weights of $R-12$ and $R-114$ are, respectively, 120.93 and 170.94. The mol fraction of R-114, $\mathrm{J}_{114}$, as a function of the mass fraction of $\mathrm{R}-114, \mathrm{x}_{114}$, 1 s

$$
\begin{aligned}
y_{114} & =\frac{x_{114} / 170.94}{x_{114} / 170.94+\left(1-x_{114}\right) / 120.93} \\
\text { or } y_{114} & =\frac{x_{114}}{1.4135-0.4135 x_{114}} \\
\text { and } x_{114} & =\frac{1.4135 y_{114}}{1+0.4135 y_{114}}
\end{aligned}
$$


2-7. Dalton's law. Dalton's law states that the total pressure of the vapor mixture is the sum of the partial pressures of the constituents

$$
p_{t}=P_{a}+P_{b}
$$

where $p_{t}=$ total pressure,

and that the partial pressures are proportional to the mol fraction,

$$
p_{\mathbf{a}}=\boldsymbol{J}_{\mathbf{a}, \mathrm{V}} \mathrm{p}_{\mathbf{t}}
$$

With a given temperature, Egs. 2-2 and 2-3 can be used to compute the saturation pressures of $R-12$ and $R-114$, designated $p_{12}$ and $p_{114}$, respectively. If the pressure $p_{t}$ is stipulated, combination of Eqs. 2-4 and 2-7 permits computation of the mol fraction of $R-114$ in the liquid

$$
J_{114, I}=\frac{p_{t}-p_{12}}{p_{114}-p_{12}}
$$

and for the vapor

$$
z_{114, v}=\frac{\left(p_{114}\right)\left(z_{114, L}\right)}{p_{t}}
$$

The mol fractions in Eqs. 2-9 and 2-10 can then be converted to mass fractions by use of $\mathrm{Eq} .2-6$.

The saturated liquid and vapor curves for several different pressures calculated using the above relationships are shown in Fig. 2-2.

2-8. Enthelpy of liquid. The enthalpies of liquid mixtures are computed by proportioning on mass basis the enthalpies of Iiquid of the two constituent substances at the given temperature. Least-squares fits were applied to tabular data for R-12 and R-114 in the range of -40 to $+40^{\circ} \mathrm{C}$ to arrive at the following equations,

$$
\begin{aligned}
& R-114: \quad h_{f, 114}=200.0+0.9545 t+0.00116 t^{2}+0.0000003 t^{3} \\
& R-12: \quad h_{f, 12}=200.0+0.9251 t+0.00081 t^{2}+0.0000048 t^{3}
\end{aligned}
$$

$$
\text { where } \begin{array}{r}
h_{f}=\text { enthalpy, } \mathrm{kJ} / \mathrm{kg} \\
\mathrm{t}=\text { temperacure, }{ }^{\circ} \mathrm{C}
\end{array}
$$




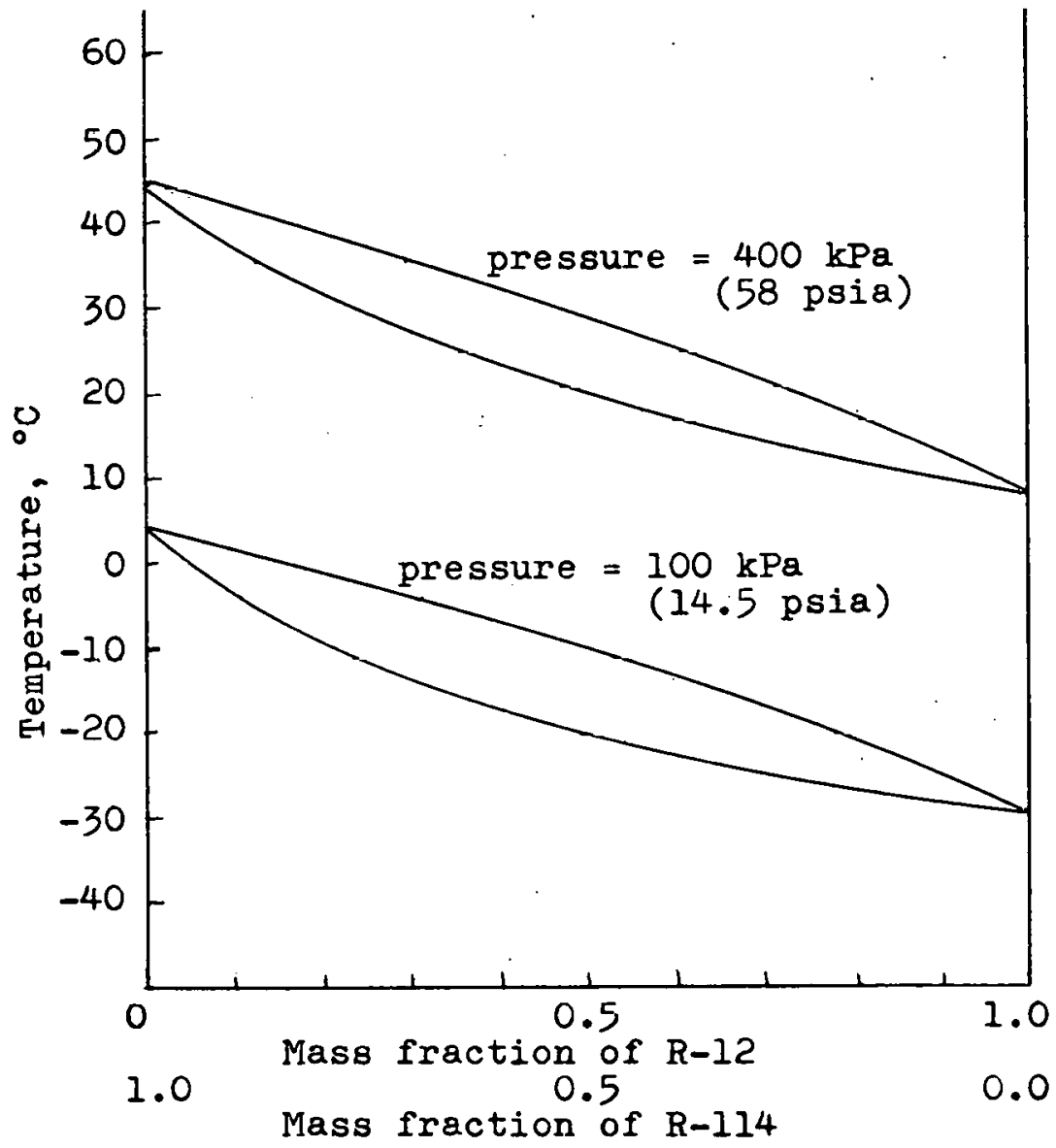

F1g. 2-2. Temperature-concentration diagram of $\mathrm{R}-12 / \mathrm{R}-114$ mixture. 
The maximum error of Eq. 2-11 is 0.12 percent and of Eq. 2-12 0.03 percent in the range of temperatures shown. 2-9. Enthalpies of saturated vapor. The enthalpies of vapor mixtures were also computed by means of a mass proportioning of the saturated vapor enthalpies of the individual substances. A leastsquares fit of a cubic equation to tabular data in the -40 to $40^{\circ} \mathrm{C}$ temperature range provided the following equations

$$
\text { R-12: } \begin{aligned}
h_{v, 12} & =351.48+0.4283 t-0.00071 t^{2}-0.0000051 t^{3} \\
\text { R-112: } h_{v, 114} & =337.41+0.6234 t+0.000086 t^{2}-0.00000385 t^{3} \\
\text { Where } h_{v} & =\text { enthalpy or saturated vapor, } \mathrm{kJ} / \mathrm{kg} \\
t & =\text { temperature, }{ }^{\circ} \mathrm{C}
\end{aligned}
$$

The maximum percent deviations of the equations from the tabular data on which they were based was 0.003 percent.

2-10. Isentropic work of compression. A simple, but reasonably accurate form of equation that is applicable for isentropic compression close to the saturated vapor region is of the form

$$
\text { where } \begin{aligned}
\Delta \mathrm{c} & =\mathrm{h}\left(1-\mathrm{T}_{1} / \mathrm{T}_{2}\right) \\
\Delta \mathrm{h} & =\text { constant } \\
\mathrm{T}_{1} & =\text { saturation temperature at start of compression } \\
\mathrm{T}_{2} & =\text { saturatiun temperature at end of compression }
\end{aligned}
$$

For the two refrigerants, the numerical values of $c$ are introduced and the saturation temperatures expressed in terms of pressures:

$$
\begin{aligned}
& \mathrm{R}-12: \Delta \mathrm{h}, \mathrm{kJ} / \mathrm{kg}=158\left(1-\frac{15.407-\ln \mathrm{p}_{2}}{15.407-\ln \mathrm{p}_{1}}\right) \\
& \mathrm{R}-114: \Delta \mathrm{h}, \mathrm{kJ} / \mathrm{kg}=188\left(1-\frac{14.861-\ln \mathrm{p}_{2}}{15.407-\ln \mathrm{p}_{1}}\right)
\end{aligned}
$$


3. SINGLE TRAIN SYSTEM WITH SINGLE EVAPORATOR

3-1. The system. The refrigeration system shown in Fig. 3-1 is the basic single-refrigerant configuration, and the first cycle analysis is one of replacing the single refrigerant, R-12, with a

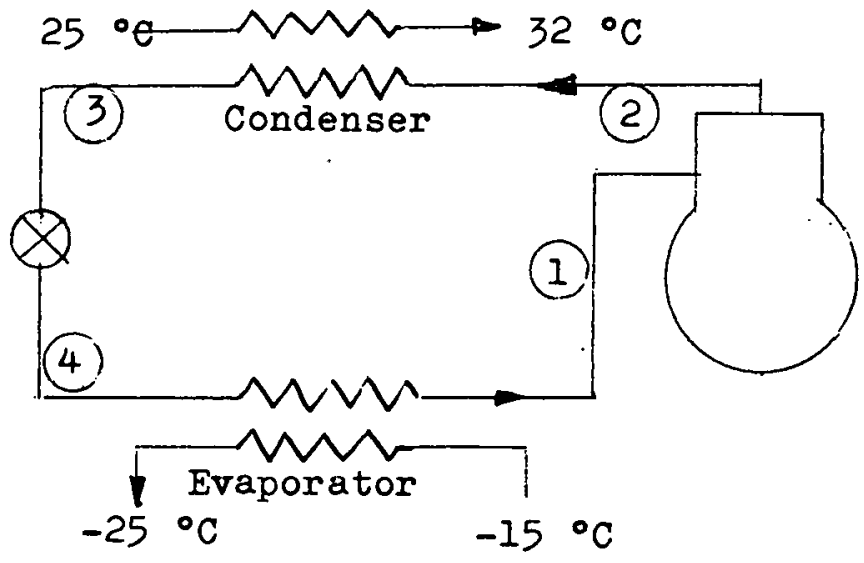

Fig. 3-1. Single-train, single-evaporator system. mixture of $R-12$ and $R-114$. To make a fair comparison of the system performance when using a mixture with that of the pure refrigerant the same heat transfer characteristics of the condenser and evaporator must be used. An improvement in COP will normally result from an increase in heat-transfer area, so the heat-transfer areas should remain constant in the comparison.

The syotem shown in Fig. 3-1 is celled gingle-train to distinguish it from a cycle presented in Chapter 5 where the refrlgerant streams follow parallel paths through a portion of the cycle.

System parameters that were stipulated and apply for the various concentrations of $R-114$ in the $R-12$ were: 
UACOND $=0.05 \mathrm{~kW} / \mathrm{K}=94.8 \mathrm{Btu} /(\mathrm{hr})\left({ }^{\circ} \mathrm{F}\right)$

UAEVAP $=0.05 \mathrm{~kW} / \mathrm{K}=94.8 \mathrm{Btu} /(\mathrm{hr})\left({ }^{\circ} \mathrm{F}\right)$

where UA refers to the product of the U-value and heat-transfer area, and COND refers to the condenser, and EVAP refers to the evaporator.

A refrigeration load of $0.2 \mathrm{~kW}(682.4 \mathrm{Btu} / \mathrm{hr})$ was chosen and this refrigeration load was used in cooling a stream from $-15^{\circ} \mathrm{C}$ to $-25^{\circ} \mathrm{C}\left(5^{\circ} \mathrm{F}\right.$ to $\left.-13^{\circ} \mathrm{F}\right)$. The condenser cooling fluid entered at $25^{\circ} \mathrm{C}$ and left at $32^{\circ} \mathrm{C}\left(77^{\circ} \mathrm{F}\right.$ to $\left.89.6{ }^{\circ} \mathrm{F}\right)$. It may be observed that the fluid being cooled changes temperature over an appreciable range. This choice was made intentionally to provide the framework for showing the potential benefit of the refrigerant mixture.

3-2. Refrigerant conditions specified. Figure 3-2 shows the $t-x-p$ diagram with numbers corresponding to the cycle diagram

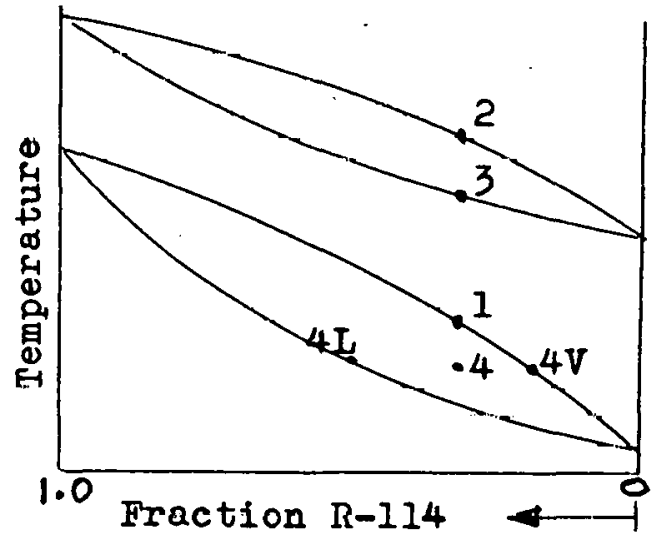

Fig. 3-2. Temperature-concentration-pressure diagram. of Fif. 3-1. The condition leaving the evaporator was assumed to be saturated vapor. For purposes of establishing the temperature, point 2 leaving the compressor is assumed to be saturated vapor. 
$-23-$

The state of this vapor will actually be superheated, but often the effect of the superheat is ignored in computing the mean temperature difference. The energy associated with the superheat must, of course, be included in the calculation. Point 3 leaving the condenser. is assumed to be saturated liquid. Point 4 following the expansion valve will be a mixture of liquid and vapor.

3-3. Simulation. To achieve a fair comparison between the system using mixtures with that of pure $R-12$ it would not be appropriate or possible to select identical refrigerant temperatures because these change with the concentration. A fairer comparison would be to perform a simulation holding the heat-transfer characteristics for the condenser and evaporator constant throughout. Such a simulation required the simultaneous solution of 18 algebraic equations, most of which were non-linear.

The necessary equations were derived from the following relationships:

1. $t-x-p$ relations at Point 1

2. $t-x-p$ relations at Point 2

3. $t-x-p$ relations at point 3

4. Enthalpy at Point 1 as function of concentration and temperature

5. Enthalpy at Point 3 as function of concentration and temperature

6. $t-x-p$ relations for liquid at Point 4

7. $t-x-p$ relations for vapor at Point 4

8. Enthalpy of liquid at Point 4

9. Enthalpy of vapor at Point 4

10. Fraction of liquid at Point 4 as a function of concentration of liquid and vapor at 4 and concentration in the system. 
11. Enthalpy of liquid-vapor mixture at 4

12. Equating enthalpy at 3 to that at 4

13. Rate equation for condenser heat transfer

14. Heat balance about condenser

15. Rate equation for evaporator heat transfer

16. Heat balance about evaporator

17. Compressor power as function of flow rate and pressures

18. Energy balance: evaporator heat transfer plus compressor power equals the rate of heat transfer at condenser These 18 equations permitted solution for the 18 unknnwn variables which were the temperature and enthalpies at Points 1 , 2, 3, and 4, the hlgh- and low-side pressures, the fraction of liquid at Point 4, the concentrations of R-114 in the liquid and vapor at Point 4, the mass rate of flow, the compressor power, and several other incidental conditions.

Following the simulation the COP's were computed for each of the concentrations,

$$
\mathrm{COP}=\frac{0.200 \mathrm{~kW} \text { refrigeration }}{\text { compressor power, } \mathrm{kW}}
$$

The results of these simulations for various concentrations are shown in the tables:

$$
\begin{aligned}
& \text { Table } 3-1 \text { O percent } R-114 \text { (100 percent } R-12 \text { ) } \\
& \text { 3-2 } 20 \text { " } \\
& \text { 3-3 } 40 \quad " \quad \\
& 3-450 \quad " \\
& 3-560 \text { " " }
\end{aligned}
$$


Table 3-1. Single-train, single evaporator system.

$$
\text { Concentration }=0.0 \text { percent } \mathrm{R}-114
$$

Refrigeration load $=0.2 \mathrm{~kW}(682.4 \mathrm{Btu} / \mathrm{hr})$

Product of U-value and area of condenser $=0.05 \mathrm{~kW} / \mathrm{K}$

$=94.8 \mathrm{Btu} /(\mathrm{hr})\left({ }^{\circ} \mathrm{F}\right)$

Product of U-value and area of evaporator $=0.05 \mathrm{~kb} / \mathrm{K}$

$=94.8 \mathrm{Btu} /(\mathrm{hr})\left({ }^{\circ} \mathrm{F}\right)$

\begin{tabular}{|l|cc|cc|}
\hline Mass rate of flow & 0.00186 & $\mathrm{~kg} / \mathrm{s}$ & 14.74 & $\mathrm{lb} / \mathrm{hr}$ \\
\hline High-side pressure & 848.4 & $\mathrm{kPa}$ & 123.0 & $\mathrm{psia}$ \\
\hline Low-side pressure & 116.4 & $\mathrm{kPa}$ & 16.9 & $\mathrm{psia}$ \\
\hline $\mathrm{t}_{1}$ & -25.9 & ${ }^{\circ} \mathrm{C}$ & -14.6 & ${ }^{\circ \mathrm{F}}$ \\
\hline $\mathrm{t}_{2}$ & 34.6 & ${ }^{\circ} \mathrm{C}$ & 94.3 & ${ }^{\circ \mathrm{F}}$ \\
\hline $\mathrm{t}_{3}$ & 34.6 & ${ }^{\circ} \mathrm{C}$ & 94.3 & ${ }^{\circ \mathrm{F}}$ \\
\hline $\mathrm{t}_{4}$ & -25.9 & ${ }^{\circ} \mathrm{C}$ & -14.6 & ${ }^{\circ} \mathrm{F}$ \\
\hline $\mathrm{h}_{1}$ & 340.9 & $\mathrm{~kJ} / \mathrm{kg}$ & 76.1 & $\mathrm{Btu} / \mathrm{Ib}$ \\
\hline $\mathrm{h}_{2}$ & 377.8 & $\mathrm{~kJ} / \mathrm{kg}$ & 92.0 & $\mathrm{Btu} / \mathrm{lb}$ \\
\hline $\mathrm{h}_{3}$ & 233.2 & $\mathrm{~kJ} / \mathrm{kg}$ & 29.77 & $\mathrm{Btu} / \mathrm{b}$ \\
\hline $\mathrm{h}_{4}$ & 233.2 & $\mathrm{~kJ} / \mathrm{kg}$ & 29.77 & $\mathrm{Btu} / \mathrm{lb}$ \\
\hline Eraction ji Iiquia at 4 & 0.65513 & & & \\
\hline Compressor power & 0.06865 & $\mathrm{~kW}$ & 0.06865 & $\mathrm{~kJ}$ \\
\hline Cop & 2.913 & & & \\
\hline
\end{tabular}


Table 3-2. Single--train, single evaporator system.

Concentration $=20$ percent $R-114$

Refrigeration load $=0.2 \mathrm{~kW}(682.4 \mathrm{Btu} / \mathrm{br})$

Product of U-value and area of condenser $=0.05 \mathrm{~kW} / \mathrm{K}$

$=94.8 \mathrm{Btu} /(\mathrm{hr})\left({ }^{\circ} \mathrm{F}\right)$

Product of U-value and area of evaporator $=0.05 \mathrm{~kW} / \mathrm{K}$

$=94.8 \mathrm{Btu} /(\mathrm{hr})\left({ }^{\circ} \mathrm{F}\right)$

\begin{tabular}{|c|c|c|c|c|}
\hline Mass rate of rlow & 0.00184 & $\mathrm{~kg} / \mathrm{s}$ & 14.6 & $1 \mathrm{~b} / \mathrm{br}$ \\
\hline Hleh-tithe pressure & 696.7 & jue & 101.0 & poia \\
\hline Low-side pressure & 93.4 & $\mathrm{kPa}$ & 13.55 & psis \\
\hline$t_{1}$ & $-21 \cdot 7$ & ${ }^{\circ} \mathrm{C}$ & -7.1 & ${ }^{\circ} \mathrm{F}$ \\
\hline$t_{2}$ & 36.5 & ${ }^{\circ} \mathrm{C}$ & $97 \cdot 7$ & ${ }^{\circ} \mathrm{F}$. \\
\hline$t_{3}$ & 31.2 & ${ }^{\circ} \mathrm{C}$ & 88.1 & ${ }^{\circ} \mathrm{F}$ \\
\hline$t_{4}$ & -27.1 & ${ }^{\circ} \mathrm{S}$ & -16.8 & ${ }^{\circ} \mathrm{F}$ \\
\hline $\mathrm{h}_{1}$ & 338.7 & $\mathrm{~kJ} / \mathrm{kg}$ & 75.1 & Btu $/ .2 b$ \\
\hline$i_{2}$ & 373.8 & $\mathrm{~kJ} / \mathrm{kg}$ & 90.2 & Btu/3b \\
\hline $\mathrm{h}_{3}$ & 230.0 & $\mathrm{~kJ} / \mathrm{kg}$ & 28.4 & $R+11 / 1 r_{1}$ \\
\hline$h_{4}$ & 230.0 & $\mathrm{~kJ} / \mathrm{kg} \mathrm{g}$ & 28.4 & Btu/Ib \\
\hline Fraction of liquid at 4 & 0.661 & & & \\
\hline Conphessot fuwer & 0.0646 & IRW & 0.0646 & $\mathrm{~kW}$ \\
\hline CUP & 3.097 & & & \\
\hline
\end{tabular}


Table 3-3. Single-train, single evaporator system. Concentration $=40$ percent R-114 Refrigeration load $=0.2 \mathrm{~kW}(682.4 \mathrm{Btu} / \mathrm{hr})$ Product of U-value and area of condenser $=0.05 \mathrm{~kW} / \mathrm{K}$ $=94.8 \mathrm{Btu} /(\mathrm{hr})\left({ }^{\circ} \mathrm{F}\right)$

Product of U-value and area of evaporator $=0.05 \mathrm{~kW} / \mathrm{K}$ $=94.8 \mathrm{Btu} /(\mathrm{br})\left({ }^{\circ} \mathrm{F}\right)$

\begin{tabular}{|l|ll|ll|}
\hline Mass rate of flow & 0.00187 & $\mathrm{~kg} / \mathrm{s}$ & 14.84 & $\mathrm{lb} / \mathrm{hr}$ \\
\hline High-side pressure & 583.6 & $\mathrm{kPa}$ & 84.6 & $\mathrm{psia}$ \\
\hline Low-side pressure & 72.5 & $\mathrm{kPa}$ & 10.5 & $\mathrm{psia}$ \\
\hline $\mathrm{t}_{1}$ & -20.5 & ${ }^{\circ} \mathrm{C}$ & -4.8 & ${ }^{\circ} \mathrm{F}$ \\
\hline $\mathrm{t}_{2}$ & 38.1 & ${ }^{\circ} \mathrm{C}$ & 100.5 & ${ }^{\circ} \mathrm{F}$ \\
\hline $\mathrm{t}_{3}$ & 29.6 & ${ }^{\circ} \mathrm{C}$ & 85.2 & ${ }^{\circ} \mathrm{F}$ \\
\hline $\mathrm{t}_{4}$ & -27.8 & ${ }^{\circ} \mathrm{C}$ & -18.1 & ${ }^{\circ} \mathrm{F}$ \\
\hline $\mathrm{h}_{1}$ & 335.6 & $\mathrm{~kJ} / \mathrm{kg}$ & 73.8 & $\mathrm{Btu} / 1 \mathrm{~b}$ \\
\hline $\mathrm{h}_{2}$ & 369.7 & $\mathrm{~kJ} / \mathrm{kg}$ & 88.4 & $\mathrm{Btu} / \mathrm{lb}$ \\
\hline $\mathrm{h}_{3}$ & 228.6 & $\mathrm{~kJ} / \mathrm{kg}$ & 27.8 & $\mathrm{Btu} / \mathrm{ib}$ \\
\hline $\mathrm{h}_{4}$ & 228.6 & $\mathrm{~kJ} / \mathrm{kg}$ & 27.8 & $\mathrm{Btu} / \mathrm{lb}$ \\
\hline Fraction of liquia at 4 & 0.657 & & & \\
\hline Corapressor power & 0.0637 & $\mathrm{kH}$ & 0.0637 & $\mathrm{~kW}$ \\
\hline Cop & 3.138 & & & \\
\hline
\end{tabular}


Table 3-4. Single-train, single evaporator system. Concentration $=50$ percent $\mathrm{R}-114$

Refrigeration load $=0.2 \mathrm{~kW}(682.4 \mathrm{Btu} / \mathrm{hr})$

Product of U-value and area of condenser $=0.05 \mathrm{~kW} / \mathrm{K}$

$=94.8 \mathrm{Btu} /(\mathrm{hr})\left({ }^{\circ} \mathrm{F}\right)$

Product of U-value and area of evaporator $=0.05 \mathrm{~kW} / \mathrm{IK}$

$=94.8 \mathrm{Btu} /(\mathrm{hr})\left({ }^{\circ} \mathrm{F}\right)$

\begin{tabular}{|c|c|c|c|c|}
\hline Mass rate of flow & 0.0019 & $\mathrm{~kg} / \mathrm{s}$ & 15.066 & $1 \mathrm{~b} / \mathrm{hr}$ \\
\hline High-side pressure & 532.6 & KHQ & 77.22 & pśiä \\
\hline Low-side pressure & 63.2 & $k P a$ & 9.16 & psia \\
\hline$t_{1}$ & -20.5 & ${ }^{\circ} \mathrm{C}$ & $-4 \cdot 9$ & ${ }^{\circ} \mathrm{F}$ \\
\hline$t_{2}$ & 38.5 & ${ }^{\circ} \mathrm{C}$ & 101.2 & ${ }^{\circ} \mathrm{F}$ \\
\hline$t_{3}$ & 29.3 & ${ }^{\circ} \mathrm{C}$ & 84.7 & ${ }^{\circ} \mathrm{F}$ \\
\hline$t_{4}$ & -27.8 & ${ }^{\circ} \mathrm{C}$ & -18.1 & ${ }^{\circ} \mathrm{F}$ \\
\hline $\mathrm{h}_{\mathrm{I}}$ & 333.8 & $\mathrm{~kJ} / \mathrm{kg}$ & 73.0 & $\mathrm{Btu} / \mathrm{Ib}$ \\
\hline $\mathrm{Hr}_{2}$ & 367.4 & $\mathrm{~kJ} / \mathrm{kg}$ & 87.5 & Btu/lo \\
\hline $\mathrm{b}_{3}$ & 228.4 & $\mathrm{~kJ} / \mathrm{lkg}$ & 27.7 & $\mathrm{Btu} / \mathrm{1b}$ \\
\hline $\mathrm{n}_{4}$ & 220.4 & $\mathrm{KJ} / \mathrm{KK}$ & 27.7 & BEi $/ 18$ \\
\hline Fraction : $\hat{I}$ Ijquid at 4 & 0.654 & & & \\
\hline Compressor power & 0.0639 & $\mathrm{kll}$ & 0.0639 & $\mathrm{~kW}$ \\
\hline cop & 3.130 & & & \\
\hline
\end{tabular}


Table 3-5. Single-train, single evaporator system. Concentration $=60$ percent $\mathrm{R}-114$

Refrigeration load $=0.2 \mathrm{~kW}(682.4 \mathrm{Btu} / \mathrm{hr})$

Product of U-value and area of condenser $=0.05 \mathrm{kw} / \mathrm{K}$

$=94.8 \mathrm{Btu} /(\mathrm{hr})\left({ }^{\circ} \mathrm{F}\right)$

Product of U-value and area or evaporator $=0.05 \mathrm{~kW} / \mathrm{K}$

$=94.8 \mathrm{Btu} /(\mathrm{hr})\left({ }^{\circ} \mathrm{g}\right)$

\begin{tabular}{|l|ll|ll|}
\hline Mass rate of flov & 0.00194 & $\mathrm{~kg} / \mathrm{s}$ & 15.37 & $\mathrm{lb} / \mathrm{hr}$ \\
\hline High-siảe pressure & 483.1 & $\mathrm{kPa}$ & 70.0 & $\mathrm{psia}$ \\
\hline Low-side pressure & 54.5 & $\mathrm{kPa}$ & 7.91 & $\mathrm{psia}$ \\
\hline $\mathrm{t}_{\mathrm{J}}$ & -20.9 & ${ }^{\circ} \mathrm{C}$ & -5.6 & ${ }^{\circ} \mathrm{F}$ \\
\hline $\mathrm{t}_{2}$ & 38.5 & ${ }^{\circ} \mathrm{C}$ & 101.3 & ${ }^{\circ} \mathrm{F}$ \\
\hline $\mathrm{t}_{3}$ & 29.2 & ${ }^{\circ} \mathrm{C}$ & 84.6 & ${ }^{\circ} \mathrm{F}$ \\
\hline $\mathrm{t}_{4}$ & -27.6 & ${ }^{\circ} \mathrm{C}$ & -17.6 & ${ }^{\circ} \mathrm{F}$ \\
\hline $\mathrm{h}_{1}$ & 331.76 & $\mathrm{~kJ} / \mathrm{kg}$ & 72.2 & $\mathrm{Btu} / 1 \mathrm{~b}$ \\
\hline $\mathrm{h}_{2}$ & 365.0 & $\mathrm{~kJ} / \mathrm{kg}$ & 86.5 & $\mathrm{Btu} / \mathrm{lb}$ \\
\hline $\mathrm{h}_{3}$ & 228.5 & $\mathrm{~kJ} / \mathrm{kg}$ & 27.8 & $\mathrm{Btu} / 1 \mathrm{~b}$ \\
\hline $\mathrm{h}_{4}$ & 228.5 & $\mathrm{~kJ} / \mathrm{kg}$ & 27.8 & $\mathrm{Btu} / \mathrm{jb}$ \\
\hline Fraction of liquid at 4 & 0.650 & & & \\
\hline Compressor power & 0.0644 & $\mathrm{~kW}$ & 0.0644 & $\mathrm{~kW}$ \\
\hline Cop & 3.107 & & & \\
\hline
\end{tabular}


3-4. COP improved through use of mixture. The major significance of Tables 3-1 through 3-5 is that they show that energy can be conserved by using a mixture of refrigerants. The COP of the system using pure R-12 was 2.913 , and this COP increased progressively with the addition of $\mathrm{R}-114$ until the maximum COP of 3.138 was achieved with a 40 percent concentration of R-114. The maximum improvement was therefore approximately 7.7 percent. Increasing the R-114 concentration above 40 percent resulted in a reduction of the COP.

Tables 3-1 through 3-5 also show the change in temperature of the refrigerant through the ovaporatur. WIth 100 percent $R-12$, as expected, the refrigerant remains at a constant temperature. That value is $-25.9{ }^{\circ} \mathrm{C}(-14.62 \mathrm{~F})$. With an R-114 concentration of 40 percent--the concentration that results in the maximum cop-..the change in refrigerant temperature in the evaporator is $7.3{ }^{\circ} \mathrm{C}$ $\left(13.4^{\circ} \mathrm{F}\right.$ ) from $-27.8^{\circ} \mathrm{C}$ to $-20.5^{\circ} \mathrm{C}$.

3-5. Single evaporator cycle with heat exchanger. Almost all of the recent analytical and experimental studies of mixed refrigerant systems have been directed toward cycles that employ a liquid-to-suction heat exchanger. Figure 3-3 shows the flow diagram of a cycle that includes a heat exchanger that subcools liquid coming from the condenser before the liquid passes through the expansion valve. The fluid on the cold side of this heat exchanger is still-boiling refrigerant which leaves the evaporator. The net effect of insertion of the heat exchanger is shown on the temperature-concentration diagram in Fig. 3-4. The change of refrigerant temperature is approximately the same for a given load on the evaporator whether or not the heat exchanger is employed. 


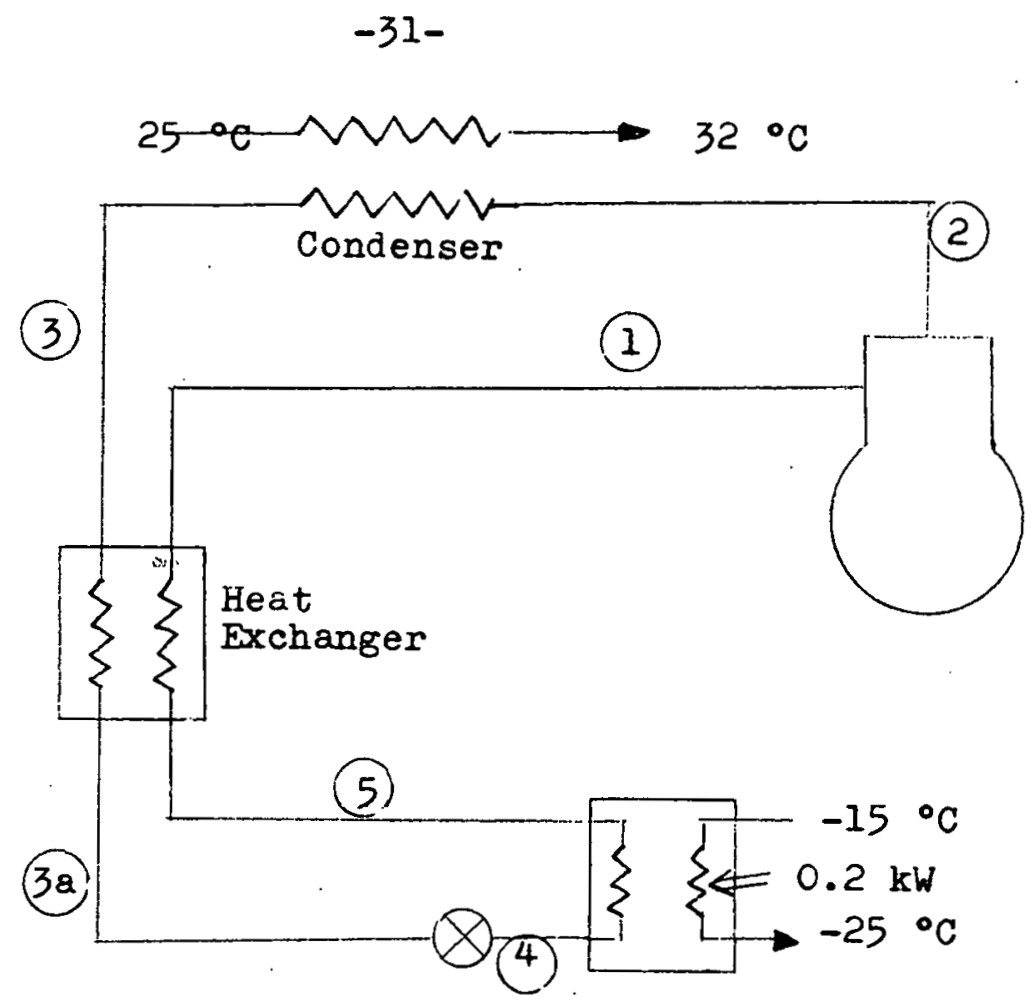

Fig. 3-3. Single-evaporator system with heat exchanger. However, the presence of the heat exchanger results in a lower temperature and enthalpy entering the expansion valve. The fraction of liquid entering the evaporator at Point 4 is thereby increased. The overall effect of the heat exchanger is to lower

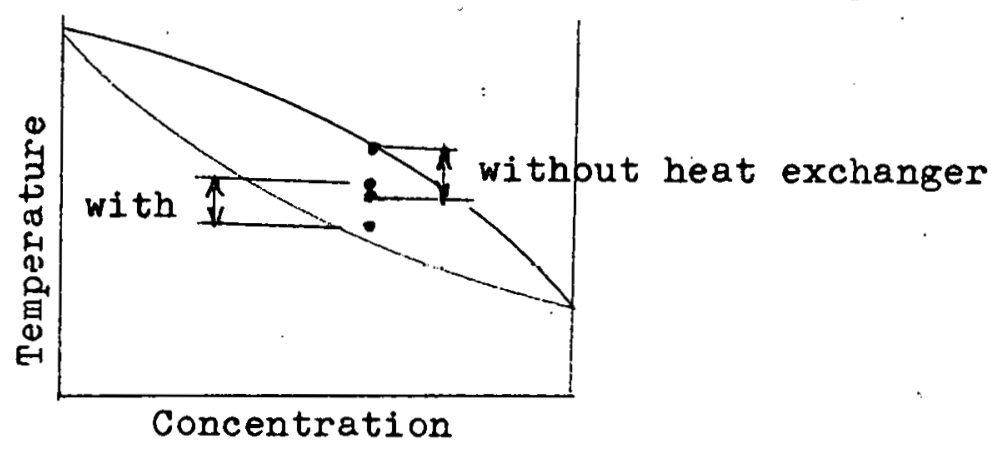

Fig. 3-4. Effect of heat exchanger on refrigerant temperatures in the evaporator.

the refrigerant temperatures in the evaporator, or conversely to 
achieve the same refrigerant temperatures in the evaporator with a higher suction pressure than is possible in the system without the heat exchanger. When the suction pressure is elevated the compressor work is reduced.

Tables 3-6 through 3-10 present the results of simulating the system in Fig. 3-3 for various concentrations of R-114. The refrigeration load, the temperatures of the fluid being cooled, and the temperatures of the condenser cooling fluid are the same as the system in Fig. 3-1 for which the results in Tables 3-1 through 3-5 apply. Point 3 in Fig. 3-3 is assumed to be saturated Liquid and foint l leaving the cola slae of the heat exchanger is saturated vapor. The zero concentration of $R-114$ (pure $R-12$ ) is not presented, because the computer simulation program using equations intended for mixtures went unstable with zero percent $R-114$. The data for 1 percent $R-114$ are presented in Table 3-6.

Some pertinent data are extracted from the complete tables and are presented in Table 3-11 in summary form. In the cycle with the heat exchanger the maximum COP of 3.310 occurs when the $\mathrm{R}-114$ concentration is 50 percent. This maximum COP is approximately 5.5 percent higher than the maximum COP of the cycle without the heat exchanger. lihe combined improvement by adding the heat exchanger and utilizing mixtures is 13.6 percent. The addition of the heat exchanger does not help the COP of the system using pure $R-12$ at all. If additional heat transfer area were available for the R-12 system it would probably be used in the evaporator. But it should be noted that the additional heat 
Table 3-6. Single-train, single evaporator, with heat exchanger Concentration $=1.0$ pexcent R-114

Refrigeration Load $=0.2 \mathrm{~kW}(682.4 \mathrm{Btu} / \mathrm{hr})$

Products of U-value and area
evaporator
$0.05 \mathrm{~kW} / \mathrm{K}$
$=94.8 \mathrm{Btu} /(\mathrm{Hr})\left({ }^{\circ} \mathrm{F}\right)$
condenser
$0.05 \mathrm{~kW} / \mathrm{K}=94.8 \mathrm{Btu} /(\mathrm{hr})\left({ }^{\circ} \mathrm{F}\right)$
heat exchanger $0.003 \mathrm{~kW} / \mathrm{K}=5.69 \mathrm{Btu} /(\mathrm{hr})\left({ }^{\circ} \mathrm{F}\right)$

\begin{tabular}{|l|ll|ll|}
\hline Mass rate of flow & $0.00185 \mathrm{~kg} / \mathrm{s}$ & 14.72 & $\mathrm{lb} / \mathrm{kr}$ \\
\hline High-side pressure & 839.2 & $\mathrm{kPa}$ & 121.7 & $\mathrm{psia}$ \\
\hline Low-side pressure & 115.6 & $\mathrm{kFa}$ & 16.8 & $\mathrm{psia}$ \\
\hline $\mathrm{t}_{1}$ & -25.5 & ${ }^{\circ} \mathrm{C}$ & -13.9 & ${ }^{\circ} \mathrm{F}$ \\
\hline$t_{2}$ & 34.7 & ${ }^{\circ} \mathrm{C}$ & 94.5 & ${ }^{\circ} \mathrm{F}$ \\
\hline$t_{3}$ & 34.3 & ${ }^{\circ} \mathrm{C}$ & 93.8 & ${ }^{\circ} \mathrm{F}$ \\
\hline$t_{3 a}$ & -14.9 & ${ }^{\circ} \mathrm{C}$ & 5.2 & ${ }^{\circ} \mathrm{F}$ \\
\hline$t_{4}$ & -25.9 & ${ }^{\circ} \mathrm{C}$ & -14.6 & ${ }^{\circ} \mathrm{F}$ \\
\hline$t_{5}$ & -25.8 & ${ }^{\circ} \mathrm{C}$ & -14.4 & ${ }^{\circ} \mathrm{F}$ \\
\hline$h_{1}$ & 340.8 & $\mathrm{~kJ} / \mathrm{kg}$ & 76.0 & $\mathrm{Btu} / \mathrm{lb}$ \\
\hline $\mathrm{h}_{2}$ & 377.7 & $\mathrm{~kJ} / \mathrm{kg}$ & 91.8 & $\mathrm{Btu} / \mathrm{Ib}$ \\
\hline $\mathrm{h}_{3}$ & 232.9 & $\mathrm{~kJ} / \mathrm{kg}$ & 29.7 & $\mathrm{Btu} / \mathrm{lb}$ \\
\hline $\mathrm{h}_{3 a}$ & 186.4 & $\mathrm{~kJ} / \mathrm{kg}$ & 9.65 & $\mathrm{Btu} / \mathrm{Ib}$ \\
\hline $\mathrm{h}_{4}$ & 186.4 & $\mathrm{~kJ} / \mathrm{kg}$ & 9.65 & $\mathrm{Btu} / \mathrm{Ib}$ \\
\hline $\mathrm{h}_{5}$ & 294.2 & $\mathrm{~kJ} / \mathrm{kg}$ & 56.0 & $\mathrm{Btu} / \mathrm{Ib}$ \\
\hline Fraction of liquid at 4 & 0.940 & & & \\
\hline Fraction of Iiquid at 5 & 0.283 & & & \\
\hline Compressor porrer & 0.0682 & $\mathrm{~kW}$ & 0.0682 & $\mathrm{kWl}$ \\
\hline Cop & 2.932 & & \\
\hline
\end{tabular}


Table 3-7. Single-train, single evaporator, with heat exchanger Concentration $=20$ percent $R-114$

Refrigeration. Load $=0.2 \mathrm{~kW}(682.4 \mathrm{Btu} / \mathrm{hr})$

Products of U-value and area

evaporator $0.05 \mathrm{~kW} / \mathrm{K}=94.8 \mathrm{Btu} /(\mathrm{hr})\left({ }^{\circ} \mathrm{F}\right)$

condensex $0.05 \mathrm{~kW} / \mathrm{K}=94.8 \mathrm{Btu} /(\mathrm{hr})\left({ }^{\circ} \mathrm{F}\right)$

heat exchanger $0.003 \mathrm{~kW} / \mathrm{K}=5.69 \mathrm{Btu} /(\mathrm{hr})\left({ }^{\circ} \mathrm{F}\right)$

\begin{tabular}{|c|c|c|c|c|}
\hline Mass rate of flow & 0.00183 & $\mathrm{~kg} / \mathrm{s}$ & 14.51 & $1 \mathrm{~b} / \mathrm{hr}$ \\
\hline High-side pressure & 696.0 & $\mathrm{kPa}$ & 100.9 & psia \\
\hline Low-stae pressure & 99.2 & $\mathrm{kPa}$ & 14.38 & psta \\
\hline$t_{1}$ & $-20 \cdot 3$ & $\dot{0}$ & -4.6 & $\dot{\partial F}$ \\
\hline$t_{2}$ & 36.5 & ${ }^{\circ} \mathrm{C}$ & 97.7 & ${ }^{\circ} \mathrm{F}$ \\
\hline$t_{3}$ & 31.1 & ${ }^{\circ} \mathrm{C}$ & 88.0 & ${ }^{\circ} \mathrm{F}$ \\
\hline$t_{3 a}$ & -12.9 & ${ }^{\circ} \mathrm{C}$ & 8.8 & $\circ$ \\
\hline$t_{4}$ & -26.6 & ${ }^{\circ} \mathrm{C}$ & $-15 \cdot 9$ & ${ }^{\circ} \mathrm{F}$ \\
\hline$t_{5}$ & -23.1 & ${ }^{\circ} \mathrm{C}$ & -9.5 & ${ }^{\circ} \mathrm{F}$ \\
\hline $\mathrm{h}_{1}$ & 339.3 & $\mathrm{~kJ} / \mathrm{kg}$ & 75.4 & Btu $/ I b$ \\
\hline$h_{2}$ & 373.5 & $\mathrm{~kJ} / \mathrm{kg}$ & 90.1 & $\mathrm{Btu} / \mathrm{Ib}$ \\
\hline $\mathrm{k}_{3}$ & 229.9 & $\mathrm{~kJ} / \mathrm{kg}$ & $28.4^{\prime}$ & $\mathrm{Bta} / \mathrm{Jb}$ \\
\hline $\mathrm{l}_{3 a}$ & 188.1 & $\mathrm{~kJ} / \mathrm{kg}$ & 10.4 & Btu/Ib \\
\hline $\mathrm{h}_{4}$ & 188.1 & $\mathrm{~kJ} / \mathrm{kg}$ & 10.4 & $B+u / I b$ \\
\hline $\mathrm{hr}_{2}$ & $297 \cdot 5$ & $\mathrm{~kJ} / \mathrm{lkg}$ & 57.4 & $\mathrm{Btu} / \mathrm{Ib}$ \\
\hline Fraction of liquid at 4 & 0.923 & & & \\
\hline Fraction of liquid at 5 & 0.255 & & . & \\
\hline Compressor power & 0.0626 & $\mathrm{~kW}$ & 0.0626 & $\mathrm{~kW}$ \\
\hline COP & 3.194 & & & \\
\hline
\end{tabular}


Table 3-8. Single-train, single evaporator, with heat exchanger. Concentration $=40$ percent $R-114$

Refrigeration Load $=0.2 \mathrm{~kW}(682.4 \mathrm{Btu} / \mathrm{hr})$

Products of U-value and area

evaporator $0.05 \mathrm{~kW} / \mathrm{K}=94.8 \mathrm{Btu} /(\mathrm{hr})\left({ }^{\circ} \mathrm{F}\right)$

condenser $\quad 0.05 \mathrm{~kW} / \mathrm{K}=94.8 \mathrm{Btu} /(\mathrm{hr})\left({ }^{\circ} \mathrm{F}\right)$

heat exchanger $0.003 \cdot \mathrm{kW} / \mathrm{K}=5.69 \mathrm{Btu} /(\mathrm{hr})\left({ }^{\circ} \mathrm{F}\right)$

\begin{tabular}{|l|ll|ll|}
\hline Mass rate of flow & $0.00185 \mathrm{~kg} / \mathrm{s}$ & 14.68 & $\mathrm{lb} / \mathrm{hr}$ \\
\hline High-side pressure & 582.5 & $\mathrm{kPa}$ & 84.5 & $\mathrm{psia}$ \\
\hline Low-side pressure & 80.0 & $\mathrm{kPa}$ & 11.6 & $\mathrm{psia}$ \\
\hline $\mathrm{t}_{1}$ & -18.2 & ${ }^{\circ} \mathrm{C}$ & -0.8 & ${ }^{\circ} \mathrm{F}$ \\
\hline $\mathrm{t}_{2}$ & 38.0 & ${ }^{\circ} \mathrm{C}$ & 100.4 & ${ }^{\circ} \mathrm{F}$ \\
\hline $\mathrm{t}_{3}$ & 29.5 & ${ }^{\circ} \mathrm{C}$ & 85.1 & ${ }^{\circ} \mathrm{F}$ \\
\hline $\mathrm{t}_{3 \mathrm{a}}$ & -11.1 & ${ }^{\circ} \mathrm{C}$ & 12.0 & ${ }^{\circ} \mathrm{F}$ \\
\hline $\mathrm{t}_{4}$ & -27.5 & ${ }^{\circ} \mathrm{C}$ & -17.5 & ${ }^{\circ} \mathrm{F}$ \\
\hline $\mathrm{t}_{5}$ & -21.0 & ${ }^{\circ} \mathrm{C}$ & -5.7 & ${ }^{\circ} \mathrm{F}$ \\
\hline $\mathrm{h}_{1}$ & 336.7 & $\mathrm{~kJ} / \mathrm{kg}$ & 74.3 & $\mathrm{Btu} / \mathrm{lb}$ \\
\hline $\mathrm{h}_{2}$ & 369.5 & $\mathrm{~kJ} / \mathrm{kg}$ & 88.4 & $\mathrm{Btu} / 1 \mathrm{~b}$ \\
\hline $\mathrm{h}_{3}$ & 228.6 & $\mathrm{~kJ} / \mathrm{kg}$ & 27.8 & $\mathrm{Btu} / \mathrm{sb}$ \\
\hline $\mathrm{h}_{3 \mathrm{a}}$ & 189.7 & $\mathrm{~kJ} / \mathrm{kg}$ & 11.1 & $\mathrm{Btu} / 1 \mathrm{~b}$ \\
\hline $\mathrm{h}_{4}$ & 189.7 & $\mathrm{~kJ} / \mathrm{kg}$ & 11.1 & $\mathrm{Btu} / \mathrm{lb}$ \\
\hline $\mathrm{h}_{5}$ & 297.8 & $\mathrm{~kJ} / \mathrm{kg}$ & 57.6 & $\mathrm{Btu} / \mathrm{lb}$ \\
\hline Fraction of liquid at 4 & 0.906 & & & \\
\hline Fraction of liquid at 5 & 0.243 & & & \\
\hline Compressor juwer & 0.0606 & $\mathrm{~kW}$ & 0.0606 & $\mathrm{~kW}$ \\
\hline cof & 3.301 & & \\
\hline
\end{tabular}


Table 3-9. Single-train, single evaporator, with heat exchanger Concentration $=50$ percent R-114 Refrigeration Load $=0.2 \mathrm{~kW}(682.4 \mathrm{Btu} / \mathrm{hr})$

Products of U-value and area

$$
\begin{aligned}
& \text { evaporator } \quad 0.05 \mathrm{~kW} / \mathrm{K}=94.8 \mathrm{Btu} /(\mathrm{hr})\left({ }^{\circ} \mathrm{F}\right) \\
& \text { condenser } \quad 0.05 \mathrm{~kW} / \mathrm{K}=94.8 \mathrm{Btu} /(\mathrm{hr})\left({ }^{\circ} \mathrm{F}\right) \\
& \text { heat exchanger } 0.003 \mathrm{~kW} / \mathrm{K}=5.69 \mathrm{Btu} /(\mathrm{hr})\left({ }^{\circ} \mathrm{F}\right)
\end{aligned}
$$

\begin{tabular}{|l|ccc|cc|}
\hline Mass rate of flow & 0.00187 & $\mathrm{~kg} / \mathrm{s}$ & 14.88 & $\mathrm{lb} / \mathrm{hr}$ \\
\hline High-side pressure & 531.6 & $\mathrm{kPa}$ & 77.1 & $\mathrm{psia}$ \\
\hline Low-side pressure & 70.49 & $\mathrm{kPa}$ & 10.22 & $\mathrm{psia}$ \\
\hline $\mathrm{t}_{1}$ & -18.0 & ${ }^{\circ} \mathrm{C}$ & -0.4 & ${ }^{\circ} \mathrm{H}$ \\
\hline $\mathrm{t}_{2}$ & 38.4 & ${ }^{\circ} \mathrm{C}$ & 101.1 & ${ }^{\circ} \mathrm{F}$ \\
\hline $\mathrm{t}_{3}$ & 29.2 & ${ }^{\circ} \mathrm{C}$ & 84.5 & ${ }^{\circ} \mathrm{F}$ \\
\hline $\mathrm{t}_{3 \mathrm{a}}$ & -10.0 & ${ }^{\circ} \mathrm{C}$ & 12.9 & ${ }^{\circ \mathrm{F}}$ \\
\hline $\mathrm{t}_{4}$ & -27.8 & ${ }^{\circ} \mathrm{C}$ & -18.1 & ${ }^{\circ} \mathrm{H}$ \\
\hline $\mathrm{t}_{5}$ & -20.4 & ${ }^{\circ} \mathrm{C}$ & -4.8 & ${ }^{\circ} \mathrm{F}$ \\
\hline $\mathrm{h}_{1}$ & 335.0 & $\mathrm{~kJ} / \mathrm{kg}$ & 73.6 & $\mathrm{Btu} / \mathrm{lb}$ \\
\hline $\mathrm{h}_{2}$ & 367.3 & $\mathrm{~kJ} / \mathrm{kg}$ & 87.5 & $\mathrm{Btu} / \mathrm{lb}$ \\
\hline $\mathrm{h}_{3}$ & 228.4 & $\mathrm{~kJ} / \mathrm{kg}$ & 27.7 & $\mathrm{Btu} / \mathrm{lb}$ \\
\hline $\mathrm{h}_{3 \mathrm{a}}$ & 190.7 & $\mathrm{~kJ} / \mathrm{kg}$ & 11.3 & $\mathrm{Bta} / \mathrm{lb}$ \\
\hline $\mathrm{h}_{4}$ & 190.1 & $\mathrm{~kJ} / \mathrm{kg}$ & 11.3 & $\mathrm{Btu} / \mathrm{lb}$ \\
\hline $\mathrm{h}_{5}$ & 296.8 & $\mathrm{~kJ} / \mathrm{kg}$ & 57.1 & $\mathrm{Btu} / \mathrm{lb}$ \\
\hline Fraction of liquid at 4 & 0.900 & & & \\
\hline Fraction of liquid Et 5 & 0.242 & & & \\
\hline Compressor power & 0.0604 & $\mathrm{~kW}$ & 0.0604 & $\mathrm{~kW}$ \\
\hline Cop & 3.310 & & & \\
\hline
\end{tabular}


Table 3-10single-train, single evaporator, with heat exchanger Concentration $=60$ percent $\mathrm{R}-114$ Refrigeration Load $=0.2 \mathrm{~kW}(682.4 \mathrm{Btu} / \mathrm{hr})$

Products of U-value and area

$$
\begin{aligned}
& \text { evaporator } 0.05 \mathrm{~kW} / \mathrm{K}=94.8 \mathrm{Btu} /(\mathrm{hr})\left({ }^{\circ} \mathrm{F}\right) \\
& \text { condenser } 0.05 \mathrm{~kW} / \mathrm{K}=94.8 \mathrm{Btu} /(\mathrm{hr})\left({ }^{\circ} \mathrm{F}\right) \\
& \text { heat exchanger } 0.003 \mathrm{~kW} / \mathrm{K}=5.69 \mathrm{Btu} /(\mathrm{hr})\left({ }^{\circ} \mathrm{F}\right)
\end{aligned}
$$

\begin{tabular}{|c|c|c|c|c|}
\hline Mass rate of flow & 0.00191 & $\mathrm{~kg} / \mathrm{s}$ & 15.16 & $\mathrm{lb} / \mathrm{hr}$ \\
\hline High-side pressure & 482.1 & $\mathrm{kPa}$ & 69.9 & psia \\
\hline Low-side pressure & 61.4 & $\mathrm{kPa}$ & 8.90 & psia \\
\hline$t_{1}$ & -18.3 & ${ }^{\circ} \mathrm{C}$ & -0.9 & ${ }^{\circ} \mathrm{F}$ \\
\hline$t_{2}$ & 38.4 & ${ }^{\circ} \mathrm{C}$ & 101.2 & ${ }^{\circ} \mathrm{F}$ \\
\hline$t_{3}$ & 29.2 & ${ }^{\circ} \mathrm{C}$ & 84.5 & ${ }^{\circ} \mathrm{F}$ \\
\hline$t_{3 a}$ & -10.2 & ${ }^{\circ} \mathrm{C}$ & 13.65 & ${ }^{\circ} \mathrm{F}$ \\
\hline$t_{4}$ & -27.9 & ${ }^{\circ} \mathrm{C}$ & -18.3 & ${ }^{\circ} \mathrm{F}$ \\
\hline$t_{5}$ & -20.3 & ${ }^{\circ} \mathrm{C}$ & -4.5 & ${ }^{\circ} \mathrm{F}$ \\
\hline $\mathrm{h}_{1}$ & 333.1 & $\mathrm{~kJ} / \mathrm{kg}$ & 72.8 & Btu/Ib \\
\hline $\mathrm{h}_{2}$ & 364.8 & $\mathrm{~kJ} / \mathrm{kg}$ & 86.4 & Btu/Ib \\
\hline $\mathrm{h}_{3}$ & 228.4 & $\mathrm{~kJ} / \mathrm{kg}$ & 27.5 & Btu/Ib \\
\hline $\mathrm{b}_{3 \mathrm{a}}$ & 190.5 & $k J / k_{B}$ & 11.4 & Btu/Ib \\
\hline $\mathrm{h}_{4}$ & 190.5 & $\mathrm{~kJ} / \mathrm{kg}$ & 11.4 & $\mathrm{Btu} / \mathrm{Ib}$ \\
\hline $\mathrm{h}_{5}$ & 295.2 & $\mathrm{~kJ} / \mathrm{kg}$ & 56.5 & Btu/Ib \\
\hline Fraction of liquid at 4 & 0.895 & & & \\
\hline Firaction ot liquid at 5 & 0.244 & & & \\
\hline Compressor poner & 0.0606 & $\mathrm{KH}$ & 0.0606 & $\mathrm{~kW}$ \\
\hline $\mathrm{COP}$ & 3.2995 & & & \\
\hline
\end{tabular}


Table.3-11. Evaporator temperatures and COP's.

\begin{tabular}{|c|c|c|c|c|c|c|}
\hline \multirow[b]{2}{*}{$\begin{array}{c}\text { Percent } \\
R-114\end{array}$} & \multicolumn{3}{|c|}{ Without heat exchanger } & \multicolumn{3}{|c|}{ With heat exchanger } \\
\hline & $\begin{array}{l}\text { Temp. ent. } \\
\text { evap., }{ }^{\circ} \mathrm{C}\end{array}$ & $\begin{array}{l}\text { Temp. Ivg. } \\
\text { evap., }{ }^{\circ} \mathrm{C}\end{array}$ & COP & $\begin{array}{l}\text { Temp. ent. } \\
\text { evap., }{ }^{\circ} \mathrm{C}\end{array}$ & $\begin{array}{l}\text { Temp. Ivg. } \\
\text { evap., }{ }^{\circ} \mathrm{C}\end{array}$ & $\mathrm{COP}$ \\
\hline 0 & -25.9 & -25.9 & 2.913 & & & \\
\hline 1 & & & & -25.9 & -25.8 & 2.932 \\
\hline 10 & -26.5 & -23.3 & 3.029 & -26.2 & -24.5 & 3.078 \\
\hline 20 & -27.1 & -21.7 & 3.097 & -26.6 & -23.1 & 3.194 \\
\hline 30 & -27.6 & -20.8 & 3.129 & -27.1 & -21.9 & 3.265 \\
\hline 40 & -27.8 & -20.5 & 3.138 & -27.5 & -21.0 & 3.301 \\
\hline 50 & -27.8 & -20.5 & 3.130 & -27.8 & -20.4 & 3.310 \\
\hline 60 & -27.6 & -20.9 & 3.107 & -27.9 & -20.3 & 3.300 \\
\hline 70 & $\ldots .7$ & -21.7 & 3.069 & & & \\
\hline
\end{tabular}

transfer capacity of the heat exchanger is relatively small--

a UA of $0.003 \mathrm{~kW} / \mathrm{K}$ in comparison to the UA of the evaporator of $0.05 \mathrm{~kW} / \mathrm{K}$.

In the evaporator, condenser, and heat exchanger counterflow has been assumed. The achievment of counterflow is important for the refrigerant mixtures which are experiencing temperature changes during condensation and evaporation. With pure refrigerants where there is no superheating or subcooling, the counterflow configuration is immaterial.

The conclusion reached from this analysis is that when the fluid being cooled in the evaporator and the condenser cooling fluid change temperatures, it is possible to conserve energy by utilizing refrigerant mixtures. A further improvement in COP results from the installation of a liquid-suction neat exchanger. 
4. SINGLE-TRAIN, TWO EVAPORATOR SYSTEM.

4-1. The two-evaporator system. The data presented in this chapter is the central analysis of the entire study, because it applies to a two-evaporator system that would be appropriate for a domestic refrigerator. Furthermore, the cycle, as shown in Fig. 4-1, is the one proposed by Lorenz and Meutzner 33 which

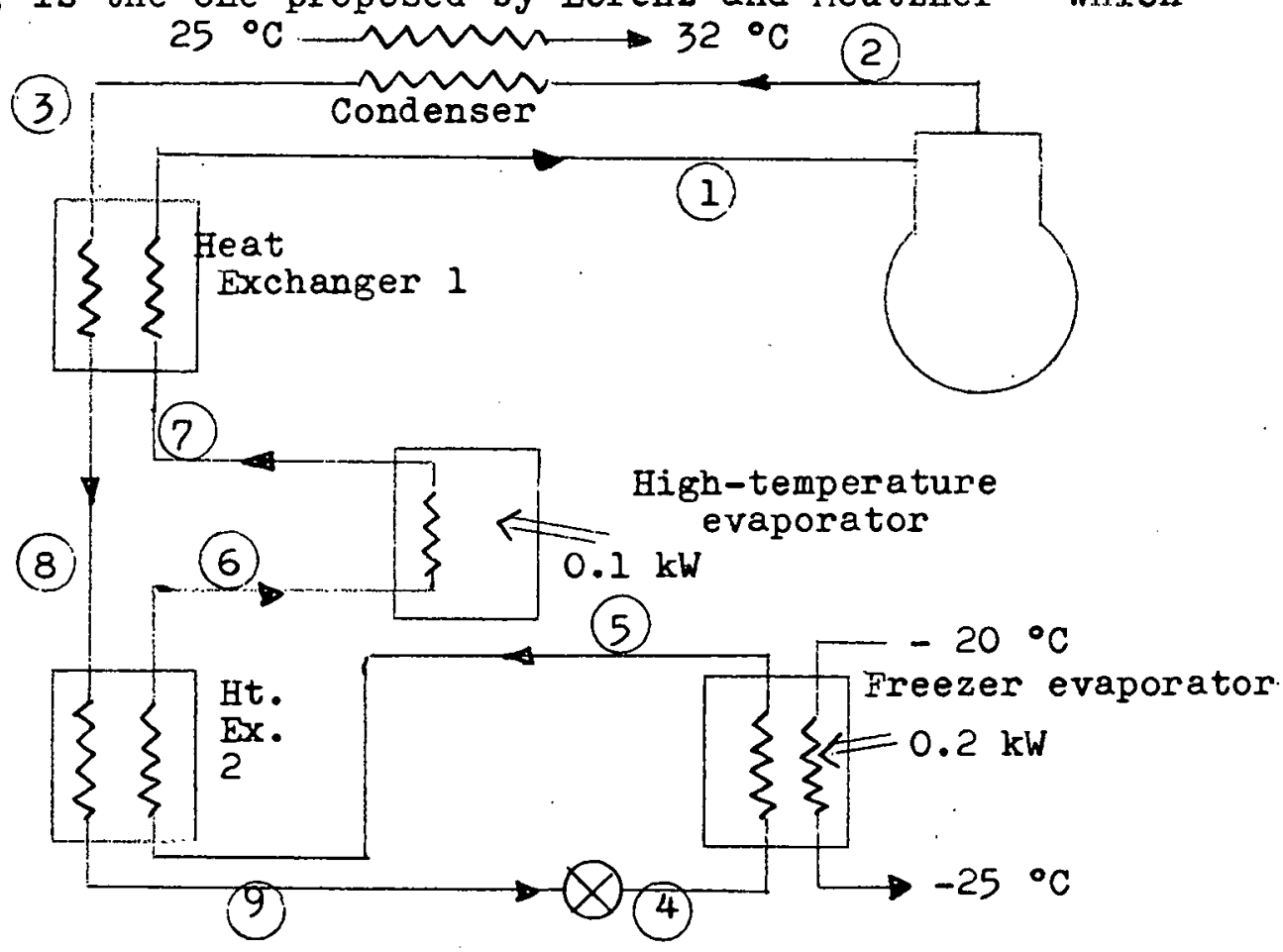

Fig. 4-1. Single-train, two-evaporator system.

reported energy savings up to 20 percent. The following specifications apply to the system:

1. Refrigeration load at low-temperature evaporator, $0.200 \mathrm{~kW}$

2. Refrigeration load at high-temperature evaporator, $0.100 \mathrm{~kW}$

3. Temperature of fluid being cooled by low-temperature evaporator,

$$
-20 \text { to }-25{ }^{\circ} \mathrm{C}
$$

4. Product of UA of evaporator, $0.05 \mathrm{~kW} / \mathrm{K}$ 
5. Product of UA of condenser, $0.05 \mathrm{~kW} / \mathrm{K}$

6. Temperature of condenser cooling fluid, 25 to $32^{\circ} \mathrm{C}$

7. Product of UA of Heat Exchanger 1, $0.003 \mathrm{~kW} / \mathrm{K}$

8. Product of UA of Heat Exchanger 2, $0.003 \mathrm{~kW} / \mathrm{K}$

9. Saturated vapor at Point 1

10. Point 2 is at the temperature of saturated vapor

11. Point 3 is saturated liquid.

4-2. Simulation of system. To simulate the system in

Fig. 4-1 with various R-114 concentrations 44 simultaneous equations were needed. These equations included properties of the refrigerant mixtures, performance characteristics of heat exchangers, material balances and energy balances. These equations appear in Appendix $B$ as they were used in the Equations Subroutine. The form of the equations correspond to the system-simulation computer program described in the paper:

Stoecker, W. F.: A Generalized Program for Steady-State System Simulation, Trans. ASHRAE, vol. 77, Part I, pp. 140-148, 1971. The results of the simulation are summarized in Tables 4-1 through 4-5. Because of the ambiguity of the COP when there are two temperature levels of evaporation, the compressor power is the quantity that indicates the expected energy requirements. The refrigeration loads are the same for all cases.

4-3. Levels of evaporating temperature. The freezer evaporator transfers $0.2 \mathrm{~kW}(682.4 \mathrm{Btu} / \mathrm{hr})$ from fluid that is dropping in temperature from $-20^{\circ} \mathrm{C}$ to $-25^{\circ} \mathrm{C}\left(-4\right.$ to $\left.-13{ }^{\circ} \mathrm{F}\right)$. The refrigeration load at the high-temperature evaporator is $0.1 \mathrm{~kW}(341.2 \mathrm{Btu} / \mathrm{hr})$, but no UA of this evaporator nor temperature of fluid being chilled 
Table 4-l. Single-Train, Two-Evaporator System Concentration $=1.0$ percent $R-114$

\begin{tabular}{|c|c|c|c|c|}
\hline Mass rate of flow & 0.00286 & $\mathrm{~kg} / \mathrm{s}$ & 22.71 & $1 \mathrm{~b} / \mathrm{hr}$ \\
\hline Blgh-side Pressure & 898.99 & $\mathrm{kPa}$ & 130.35 & psia \\
\hline Low-side Pressure & 110.46 & $\mathrm{kPa}$ & 16.02 & psia \\
\hline$t_{1}$ & -26.6 & ${ }^{\circ} \mathrm{C}$ & -15.9 & ${ }^{\circ} \mathrm{F}$ \\
\hline$t_{2}$ & 37.3 & ${ }^{\circ} \mathrm{C}$ & 99.2 & ${ }^{\circ} \mathrm{F}$ \\
\hline$t_{3}$ & 37.0 & ${ }^{\circ} \mathrm{C}$ & 98.6 & ${ }^{\circ} \mathrm{F}$ \\
\hline$t_{4}$ & -27.0 & ${ }^{\circ} \mathrm{C}$ & -16.7 & ${ }^{\circ} \mathrm{F}$ \\
\hline$t_{5}$ & -27.0 & ${ }^{\circ} \mathrm{C}$ & -16.5 & ${ }^{\circ} \mathrm{F}$ \\
\hline$t_{6}$ & -26.9 & ${ }^{\circ} \mathrm{C}$ & -16.5 & ${ }^{\circ} \mathrm{F}$ \\
\hline$t_{7}$ & -26.9 & ${ }^{\circ} \mathrm{C}$ & -16.3 & ${ }^{\circ} \boldsymbol{F}$ \\
\hline$t_{8}$ & -5.4 & ${ }^{\circ} \mathrm{C}$ & 22.2 & ${ }^{\circ} \mathrm{F}$ \\
\hline$t_{9}$ & -20.2 & ${ }^{\circ} \mathrm{C}$ & -4.3 & ${ }^{\circ} \mathrm{F}$ \\
\hline$h_{1}$ & 340.4 & $\mathrm{~kJ} / \mathrm{kg}$ & 75.9 & Btu/1b \\
\hline $\mathrm{h}_{2}$ & 379.1 & $\mathrm{~kJ} / \mathrm{kg}$ & 92.5 & Btu/1b \\
\hline$h_{3}$ & 235.6 & $\mathrm{~kJ} / \mathrm{kg}$ & 30.8 & Btu/lb \\
\hline $\mathrm{h}_{4}$ & 181.6 & $\mathrm{~kJ} / \mathrm{kg}$ & 7.60 & Btu/lb \\
\hline $\mathrm{h}_{5}$ & 251.5 & $\mathrm{~kJ} / \mathrm{kg}$ & 37.6 & Btu/lb \\
\hline $\mathrm{h}_{6}$ & 264.9 & $\mathrm{~kJ} / \mathrm{kg}$ & 43.4 & Btu/Ib \\
\hline $\mathrm{h}_{7}$ & 299.8 & $\mathrm{~kJ} / \mathrm{kg}$ & 58.4 & Btu/Ib \\
\hline $\mathrm{h}_{8}$ & 195.0 & $\mathrm{~kJ} / \mathrm{kg}$ & 13.3 & Btu/Ib \\
\hline $\mathrm{h}_{9}$ & 181.6 & $\mathrm{~kJ} / \mathrm{kg}$ & 7.6 & $\mathrm{Btu} / \mathrm{Ib}$ \\
\hline Fraction of Iiquid at 4 & 0.9628 & & & \\
\hline Fraction of Iiquid at 5 & 0.5390 & & & \\
\hline Fraction of Liquid at 6 & 0.4579 & & & \\
\hline Fraction of Liquid at $?$ & 0.2461 & & & \\
\hline Compressor power & 0.1108 & $\mathrm{~kW}$ & 0.1108 & $\mathrm{~kW}$ \\
\hline
\end{tabular}


Table 4-2. Single-Train, Two-Evaporator System Concentration $=20$ percent $R-114$

\begin{tabular}{|c|c|c|c|c|}
\hline Mass rate of flow & 0.00283 & $\mathrm{~kg} / \mathrm{s}$ & 22.42 & $1 \mathrm{~b} / \mathrm{hr}$ \\
\hline H1gh-side Pressure & 750.7 & $\mathrm{kPa}$ & 108.9 & psia \\
\hline Low-side Pressure & 95.6 & $\mathrm{kPa}$ & 13.86 & psia \\
\hline$t_{1}$ & -21.2 & ${ }^{\circ} \mathrm{C}$ & -6.1 & ${ }^{\circ} \mathrm{P}$ \\
\hline$t_{2}$ & 39.2 & ${ }^{\circ} \mathrm{C}$ & 102.6 & ${ }^{\circ} \mathrm{F}$ \\
\hline$t_{3}$ & 33.9 & ${ }^{\circ} \mathrm{C}$ & 93.0 & $\stackrel{\circ}{ }$ \\
\hline$t_{4}$ & -27.6 & ${ }^{\circ} \mathrm{C}$ & -17.6 & ${ }^{\circ} \mathrm{F}$ \\
\hline$t_{5}$ & -25.9 & ${ }^{\circ} \mathrm{C}$ & -14.6 & ${ }^{\circ} \mathrm{F}$ \\
\hline$t_{6}$ & -25.4 & ${ }^{\circ} \mathrm{C}$ & -13.7 & ${ }^{\circ} \mathrm{F}$ \\
\hline$t_{7}$ & -23.7 & ${ }^{\circ} \mathrm{C}$ & -10.6 & ${ }^{\circ} \mathrm{F}$ \\
\hline$t_{8}$ & -4.0 & ${ }^{\circ} \mathrm{C}$ & 24.8 & ${ }^{\circ} \mathrm{F}$ \\
\hline$t_{9}$ & -18.9 & ${ }^{\circ} \mathrm{C}$ & -2.1 & ${ }^{\circ} \mathrm{F}$ \\
\hline $\mathrm{h}_{1}$ & 338.9 & $\mathrm{~kJ} / \mathrm{kg}$ & 75.2 & Btu/lb \\
\hline $\mathrm{h}_{2}$ & 374.9 & $\mathrm{~kJ} / \mathrm{kg}$ & 90.7 & Btu/1b \\
\hline $\mathrm{h}_{3}$ & 232.8 & $\mathrm{~kJ} / \mathrm{kg}$ & 29.6 & $\mathrm{Btu} / \mathrm{Ib}$ \\
\hline $\mathrm{h}_{4}$ & 182.6 & $\mathrm{~kJ} / \mathrm{kg}$ & 8.05 & Btu/Ib \\
\hline $\mathrm{h}_{5}$ & 253.4 & $\mathrm{~kJ} / \mathrm{kg}$ & 38.5 & Btu/lb \\
\hline $\mathrm{n}_{6}$ & 267.1 & $\mathrm{~kJ} / \mathrm{kg}$ & 44.3 & Btu/Ib \\
\hline $\mathrm{b}_{7}$ & 302.5 & $\mathrm{~kJ} / \mathrm{lrg}$ & 59.6 & $\mathrm{Btu} / \mathrm{lb}$ \\
\hline$h_{8}$ & 196.3 & $\mathrm{~kJ} / \mathrm{kg}$ & 13.9 & Btu/lb \\
\hline $\mathrm{b}_{9}$ & 182.6 & $\mathrm{~kJ} / \mathrm{kg}$ & 8.05 & Btu/lb \\
\hline Fraction of Ijiquid at 4 & 0.9522 & & & \\
\hline Fraction of Iiquid at 5 & 0.5203 & & & \\
\hline Fraction of Liquid at 6 & 0.4374 & & & \\
\hline Fraction of Liquid at ? & 0.2222 & & & \\
\hline Compressor power & 0.1020 & $\mathrm{~kW}$ & 0.1020 & $\mathrm{~kW}$ \\
\hline
\end{tabular}


$-43-$

Table 4-3. Single-Train, Two-Evaporator System Concentration $=40$ percent $\mathrm{R}-114$

\begin{tabular}{|c|c|c|c|c|}
\hline Mass rate of flow & 0.00286 & $\mathrm{~kg} / \mathrm{s}$ & 22.67 & $1 \mathrm{~b} / \mathrm{hr}$ \\
\hline H1gh-side Pressure & 629.2 & $\mathbf{k P a}$ & 91.2 & psia \\
\hline Low-side Pressure & 77.8 & $\mathbf{k P a}$ & 11.3 & psia \\
\hline$t_{1}$ & $-18 \cdot 9$ & ${ }^{\circ} \mathrm{C}$ & -1.9 & ${ }^{\circ} \mathrm{F}$ \\
\hline$t_{2}$ & $40 . ?$ & ${ }^{\circ} \mathrm{C}$ & 105.2 & $\circ \mathrm{F}$ \\
\hline$t_{3}$ & $32 \cdot 3$ & ${ }^{\circ} \mathrm{C}$ & 90.1 & $\circ F$ \\
\hline$t_{4}$ & -28.4 & ${ }^{\circ} \mathrm{C}$ & -19.1 & ${ }^{\circ} \mathrm{F}$ \\
\hline$t_{5}$ & $-24 \cdot 7$ & ${ }^{\circ} \mathrm{C}$ & -12.5 & ${ }^{\circ} \mathrm{F}$ \\
\hline$t_{6}$ & -23.8 & ${ }^{\circ} \mathrm{C}$ & -10.8 & ${ }^{\circ} \mathrm{F}$ \\
\hline$t ?$ & $-21 \cdot 2$ & ${ }^{\circ} \mathrm{C}$ & -6.2 & $\circ \mathrm{F}$ \\
\hline$t_{8}$ & -2.6 & ${ }^{\circ} \mathrm{C}$ & $27 \cdot 3$ & ${ }^{\circ} \mathrm{F}$ \\
\hline$t_{9}$ & $-17 \cdot 5$ & ${ }^{\circ} \mathrm{C}$ & 0.6 & ${ }^{\circ} \mathrm{F}$ \\
\hline$h_{1}$ & 336.4 & $\mathrm{~kJ} / \mathrm{kg}$ & 74.16 & Btu/Ib \\
\hline $\mathrm{b}_{2}$ & 370.7 & $\mathrm{~kJ} / \mathrm{kg}$ & 88.9 & $\mathrm{Btu} / \mathrm{Ib}$ \\
\hline $\mathrm{h}_{3}$ & 231.4 & $\mathrm{~kJ} / \mathrm{kg}$ & 29.0 & $\mathrm{Btu} / \mathrm{Ib}$ \\
\hline $\mathrm{h}_{4}$ & 183.9 & $\mathrm{~kJ} / \mathrm{kg}$ & 8.61 & $\mathrm{Btu} / \mathrm{Ib}$ \\
\hline$h_{5}$ & 253.9 & $\mathrm{~kJ} / \mathrm{kg}$ & 38.7 & Btu/Ib \\
\hline $\mathrm{h}_{6}$ & 267.6 & $\mathrm{~kJ} / \mathrm{kg}$ & 44.6 & Btu/Ib \\
\hline $\mathrm{h}_{7}$ & 302.6 & $\mathrm{~kJ} / \mathrm{kg}$ & 59.6 & $B t u / 1 b$ \\
\hline$h_{8}$ & 197.6 & $\mathrm{~kJ} / \mathrm{kg}$ & 14.5 & $B t u / I b$ \\
\hline $\mathrm{h}_{9}$ & 183.9 & $\mathrm{~kJ} / \mathrm{kg}$ & 8.61 & Btu/Ib \\
\hline Fraction of Iiquid at 4 & 0.9378 & & & \\
\hline Fraction of Iiquid at 5 & 0.5100 & & & \\
\hline Fraction of Liquid at 6 & 0.4266 & & & \\
\hline Fraction of Iiquid at 7 & 0.2111 & & & \\
\hline Compressor power & 0.09824 & $\mathrm{~kW}$ & 0.09824 & $\mathrm{~kW}$ \\
\hline
\end{tabular}


Table 4-4. Single-Train, Two-Evaporator System

Concentration $=50$ percent $\mathrm{R}-114$

\begin{tabular}{|c|c|c|c|c|}
\hline Mass rate of flow & 0.00290 & $\mathrm{~kg} / \mathrm{s}$ & 22.99 & $1 \mathrm{~b} / \mathrm{hr}$ \\
\hline High-side Pressure & $574: 4$ & $\mathrm{kPa}$ & 83.3 & psia \\
\hline Low-side Pressure & 68.5 & $\mathbf{k P a}$ & 9.93 & psia \\
\hline$t_{1}$ & $-18 \cdot 7$ & ${ }^{\circ} \mathrm{C}$ & -1.6 & ${ }^{\circ} \mathrm{F}$ \\
\hline$t_{2}$ & 41.1 & ${ }^{\circ} \mathrm{C}$ & 105.9 & ${ }^{\circ} \mathrm{F}$ \\
\hline$t_{3}$ & 31.9 & ${ }^{\circ} \mathrm{C}$ & 89.5 & $n$ \\
\hline$t_{4}$ & -28.8 & ${ }^{\circ} \mathrm{C}$ & -19.8 & ${ }^{\circ} \mathrm{F}$ \\
\hline$t_{5}$ & $-24 \cdot 2$ & ${ }^{\circ} \mathrm{C}$ & -11.6 & ${ }^{\circ} \mathrm{F}$ \\
\hline$t_{6}$ & -23.2 & ${ }^{\circ} \mathrm{C}$ & -9.79 & ${ }^{\circ} \mathrm{F}$ \\
\hline$t_{7}$ & -20.7 & ${ }^{\circ} \mathrm{C}$ & $-5 \cdot 3$ & ${ }^{\circ} \mathrm{F}$ \\
\hline$t_{8}$ & -2.1 & ${ }^{\circ} \mathrm{C}$ & 28.2 & $\circ \mathrm{F}$ \\
\hline$t_{9}$ & -16.8 & ${ }^{\circ} \mathrm{C}$ & 1.7 & ${ }^{\circ} \mathrm{F}$ \\
\hline $\mathrm{h}_{1}$ & 334.7 & $\mathrm{~kJ} / \mathrm{kg}$ & 73.4 & Btu/Ib \\
\hline $\mathrm{h}_{2}$ & 368.5 & $\mathrm{~kJ} / \mathrm{kg}$ & 87.9 & Btu/Ib \\
\hline$b_{3}$ & 231.1 & $\mathrm{~kJ} / \mathrm{kg}$ & 28.9 & Btu/Ib \\
\hline$b_{4}$ & 184.5 & $\mathrm{~kJ} / \mathrm{kg}$ & 8.8 & Btu/Ib \\
\hline $\mathrm{h}_{5}$ & 253.5 & $\mathrm{~kJ} / \mathrm{kg}$ & 38.5 & $B t u / I b$ \\
\hline $\mathrm{h}_{6}$ & 267.1 & $\mathrm{~kJ} / \mathrm{kg}$ & 44.4 & Btu/lb \\
\hline$u_{7}$ & 301.6 & $\mathrm{~kJ} / \mathrm{k}_{8}$ & 59.2 & Btu/lo \\
\hline$h_{8}$ & 198.0 & $\mathrm{~kJ} / \mathrm{kg}$ & 14.7 & $B t u / l b$ \\
\hline $\mathrm{h}_{9}$ & $184 \cdot 5$ & $\mathrm{~kJ} / \mathrm{kg}$ & 8.84 & $\mathrm{Btu} / \mathrm{Ib}$ \\
\hline Fraction of Liquid at 4 & 0.9310 & & & \\
\hline Fraction of Iiquid at 5 & 0.5088 & & & \\
\hline Fraction of Iiquid at 6 & 0.4252 & & & \\
\hline Fraction of Iiquid at $?$ & 0.2101 & & & \\
\hline Compressor power & 0.09799 & $\mathrm{~kW}$ & 0.09799 & $\mathrm{~kW}$ \\
\hline
\end{tabular}


$-45-$

Table 4-5. Single-Train, Two-Evaporator System Concentration $=60$ percent $\mathrm{R}-114$

\begin{tabular}{|c|c|c|c|c|}
\hline Mass rate of flow & 0.00296 & $\mathrm{~kg} / \mathrm{s}$ & 23.46 & $1 \mathrm{~b} / \mathrm{hr}$ \\
\hline High-side Pressure & 521.6 & $\mathrm{kPa}$ & 75.6 & psia \\
\hline Low-side Pressure & 59.3 & $\mathrm{kPa}$ & 8.60 & psia \\
\hline$t_{1}$ & -19.1 & ${ }^{\circ} \mathrm{C}$ & -2.3 & ${ }^{\circ} \mathrm{F}$ \\
\hline$t_{2}$ & 41.1 & ${ }^{\circ} \mathrm{C}$ & 106.1 & ${ }^{\circ} \mathrm{F}$ \\
\hline$t_{3}$ & 31.9 & ${ }^{\circ} \mathrm{C}$ & 89.4 & ${ }^{\circ} \mathbf{F}$ \\
\hline$t_{4}$ & -29.1 & ${ }^{\circ} \mathrm{C}$ & -20.3 & ${ }^{\circ} \mathrm{F}$ \\
\hline$t_{5}$ & -23.9 & ${ }^{\circ} \mathrm{C}$ & -11.1 & ${ }^{\circ} \mathrm{F}$ \\
\hline$t_{6}$ & -23.0 & ${ }^{\circ} \mathrm{C}$ & -9.3 & ${ }^{\circ} \mathrm{F}$ \\
\hline$t_{7}$ & -20.8 & ${ }^{\circ} \mathrm{C}$ & -5.4 & ${ }^{\circ} \mathrm{F}$ \\
\hline$t_{8}$ & -1.8 & ${ }^{\circ} \mathrm{C}$ & 28.9 & ${ }^{\circ} \mathrm{F}$ \\
\hline$t_{9}$ & -16.3 & ${ }^{\circ} \mathrm{C}$ & 2.63 & ${ }^{\circ} \mathrm{F}$ \\
\hline$b_{1}$ & 332.7 & $\mathrm{~kJ} / \mathrm{kg}$ & 72.6 & Btu/Ib \\
\hline $\mathrm{b}_{2}$ & 366.0 & $\mathrm{~kJ} / \mathrm{kg}$ & 86.9 & $\mathrm{Btu} / \mathrm{Ib}$ \\
\hline $\mathrm{b}_{3}$ & 231.2 & $\mathrm{~kJ} / \mathrm{kg}$ & 29.0 & $\mathrm{Btu} / \mathrm{Lb}$ \\
\hline$h_{4}$ & 184.9 & $\mathrm{~kJ} / \mathrm{kg}$ & 9.03 & Btu/Ib \\
\hline $\mathrm{b}_{5}$ & 252.5 & $\mathrm{~kJ} / \mathrm{kg}$ & 38.1 & Btu/1b \\
\hline $\mathrm{h}_{6}$ & 266.0 & $\mathrm{~kJ} / \mathrm{kg}$ & 43.9 & Btu/1b \\
\hline $\mathrm{b}_{7}$ & 299.9 & $\mathrm{~kJ} / \mathrm{kg}$ & 58.5 & Btu/1b \\
\hline $\mathrm{h}_{8}$ & 198.4 & $\mathrm{~kJ} / \mathrm{kg}$ & 14.8 & Btu/1b \\
\hline $\mathrm{h}_{9}$ & 185.9 & $\mathrm{~kJ} / \mathrm{kg}$ & 9.02 & Btu/lb \\
\hline Fraction of Iiquid at 4 & 0.9256 & & & \\
\hline Fraction of Liquid at 5 & 0.5101 & & & \\
\hline Fraction of Iiquid at 6 & 0.4260 & & & \\
\hline Fraction of Liquid at? & 0.2118 & & & . \\
\hline Compressor power & 0.09864 & $\mathrm{~kW}$ & 0.09864 & $\mathrm{kw}$ \\
\hline
\end{tabular}


could be specified. The attempt to specify the load at the high-temperature evaporator in this way was unsuccessful, because the system was then over-specified, and conflicted with the requirement of saturated vapor at Point 1 . The behavior of an actual system where the heat-transfer characteristics would have to be satisfied would normally result in the condition at Point 1 being something other than saturated vapor--either liquid-vapor mixture or superheated vapor.

The temperature of evaporating refrigerant in the hightemperature evaporator is of the order of $-20^{\circ} \mathrm{C}\left(-4{ }^{\circ} \mathrm{F}\right)$ which is sufficiently low for the high-temperature evaporator (and perhaps even lower than desired).

4-4. Energy requirements. The primary focus of the study was on energy conservation, so the compressor power at the various refrigerant concentrations is of crucial interest. Table 4-6 summarizes the power requirements. Because of the instability of Table 4-6. Compressor power requirements of two-evaporator system

\begin{tabular}{|c|c|} 
Percent R-114 & Compressor power, kW \\
\hline 0.0 & 0.1113 (est.) \\
1.0 & 0.1108 \\
10 & $0.7 n 59$ \\
20 & 0.1020 \\
30 & 0.0995 \\
40 & 0.09828 \\
50 & 0.09799 \\
60 & 0.07864 \\
\hline
\end{tabular}


the computer program at zero percent $R-114$, the lowest $R-114$ concentration examined was 1 percent. The minimum power was required for a 50 percent mixture of $R-114$ and $R-12$. The power at this concentration was 12 percent less than that for pure R-12. 
5. SEPARATING CYCLE IN A TWO-EVAPORATOR REFRIGERATOR 5-1. Two-condenser system. Kazacki ${ }^{19}$ and the brief patent description by Labochnik ${ }^{29}$ both outline a cycle applicable to a two-evaporator refrigerator wherein a separation of the mixture into a lighter and a heavier fraction occurs. The low-temperature fraction performs the refrigeration in the freezer, and the hightemperature fraction in the high-temperature evaporator. The cycle is shown in Fig. 5-1. Suction vapor at Point 1 is compressed

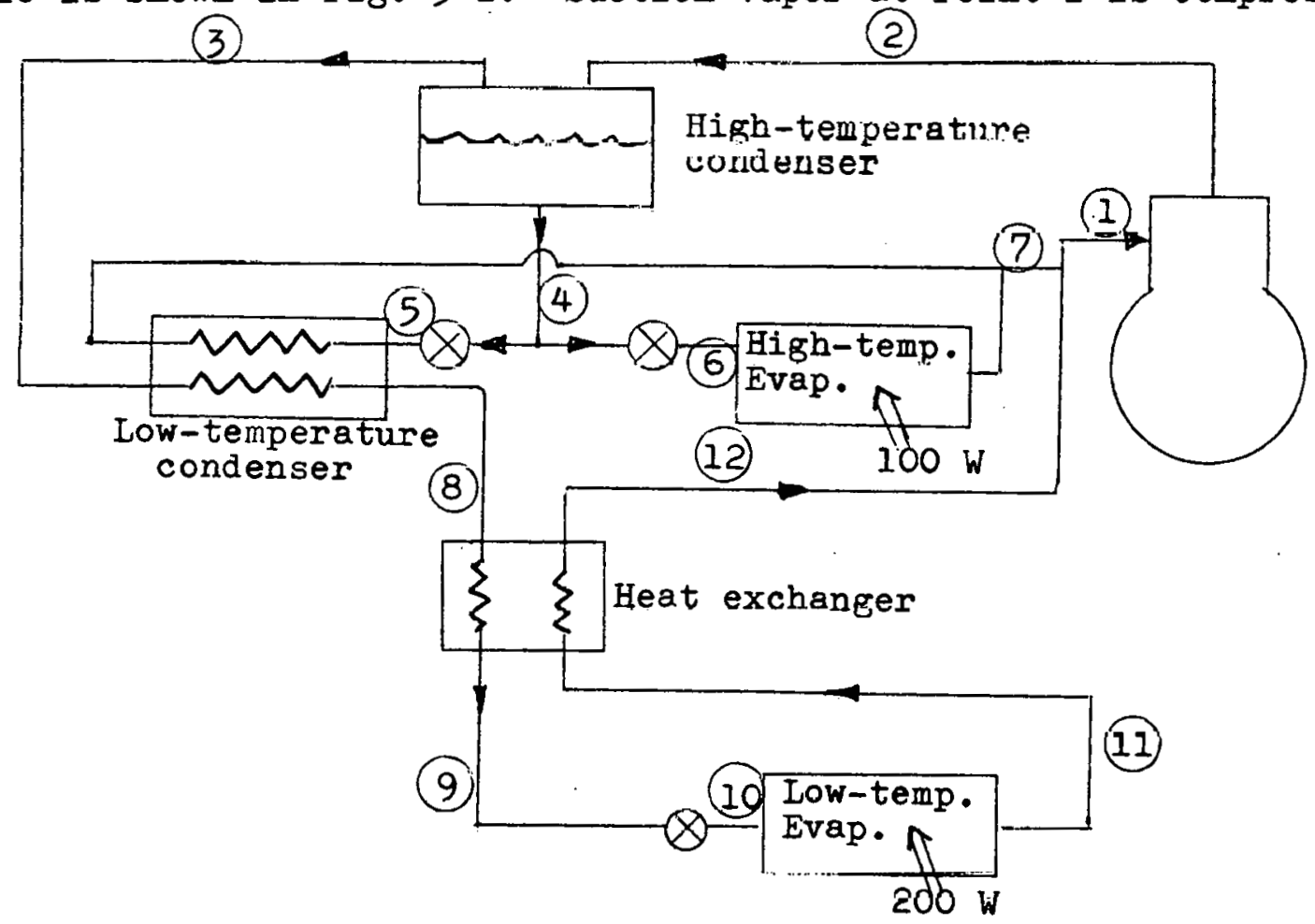

Fig. 5-1. Separating cycle with two evaporators.

to Point 2 where it enters the high-temperature condenser. Following a partial condengation, llquid that is rich in high boiling-temperature refrigerant leaves at Point 4 and vapor that 
is rich in the low boiling-temperature component leaves at Point 3. In the low-temperature condenser the vapor condenses by virtue of heat removal by evaporating liquid at Point 5. A heat exchanger cools the low-boiling-temperature liquid from Point 8 to Point 9. This liquid then passes in sequence through the expansion valve, the freezer evaporator, and the cold side of the heat exchanger. Three streams of low-pressure vapor mix to form the combinations at point 1.

The temperature-concentration diagram for the cycle is shown in Fig. 5-2. The t-x diagram further shows certain

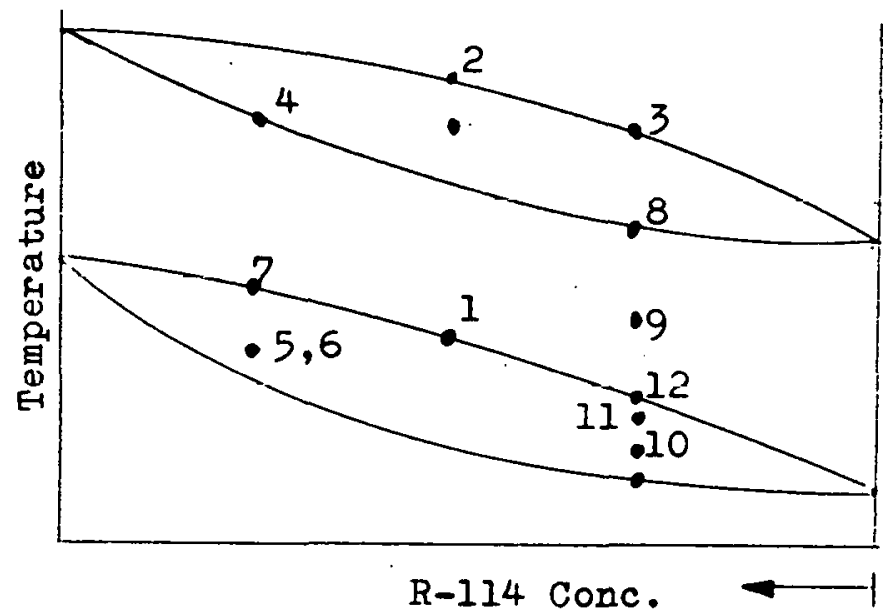

Fig. 5-2. Temperature-concentration diagram for separating cycle.

conditions that have arbitrarily been specified in the cycle, namely saturated liquid at Point 8 and saturated vapor at Points 7 and 12 .

5-2. Energy analysis of the separating cycle. An analysis was conducted on this system and the refrigeration loads of the high-temperature and freezer evaporators were the same as used in 
the single-train system of Chapter 4. It was not possible to duplicate the temperature conditions that prevailed in the singletrain system, because the two cycles are unrelated. Instead, then, an analysis of this cycle was performed by selecting the highside and low-side pressures and by stipulating the temperatures: $t_{3}=t_{4}=30^{\circ} \mathrm{C}\left(86^{\circ} \mathrm{F}\right)$ and $t_{9}=0^{\circ} \mathrm{C}\left(32^{\circ} \mathrm{F}\right)$. With those variables specified, it is possible to calculate sequentially through the system and determine all other properties and mass flow rates. By repeated choices of different high-side pressures a sutisfactory separation between Points 3 and 4 could be achieved, and by repealed cholces of low-side pressires a value that provides satisfactory freezer evaporator temperatures was found. The results of the analysis of one such cycle with 500 and $100 \mathrm{kPa}$ pressures on the high and low side, respectively, are shown in Table 5-1.

\section{5-3. Energy characteristics of the separating cycle. The} power required by the cycle is $0.1259 \mathrm{~kW}$ which is actually greater than the power required by a cycle using pure $R-12$. The R-12 sjole that was tho badio of comparison performed the full $0.3000 \mathrm{~kW}$ of refrigeration at an evaporating temperature of $-27^{\circ} \mathrm{C}\left(-17^{\circ} \mathrm{F}\right)$ and required $0.1096 \mathrm{~kW}$ compressor power. The regults are therefore discouraging, but it still may be profitable to investigate the cycle further.

In the first place the separation process assumed in the high temperature condenser is the poorest possible. Kazacki recommends a rectifying column, and Labochnik shows a rectifying column where the top section is cooled and the bottom section heated by appropriate refrigerant streams. Such a column 
Table 5-1. Analysis of separating cycle.

\begin{tabular}{|c|c|c|}
\hline High-side pressure & $500 \mathrm{kPa}$ & 72.5 psia \\
\hline Low-side pressure & $100 \mathrm{kPa}$ & $14.5 \mathrm{psia}$ \\
\hline Fraction $\mathrm{R}-114$ at 2 & 0.4944 & \\
\hline Fraction $R-114$ at 3 & 0.3254 & \\
\hline Fraction $R-114$ at 4 & 0.5884 & \\
\hline Mass flow rate at 1 & $0.004742 \mathrm{~kg} / \mathrm{s}$ & $37.6 .1 \mathrm{~b} / \mathrm{hr}$ \\
\hline Mass flow rate at 5 & $0.002139 \mathrm{~kg} / \mathrm{s}$ & $17.01 \mathrm{~b} / \mathrm{hr}$ \\
\hline Mass flow rate at 6 & $0.00091 \mathrm{~kg} / \mathrm{s}$ & $7.21 \mathrm{~b} / \mathrm{hr}$ \\
\hline Mass flow rate at 12 & $0.00169 \mathrm{~kg} / \mathrm{s}$ & $13.4 \mathrm{lb} / \mathrm{hr}$ \\
\hline$t_{2}$ & $36.1 \quad{ }^{\circ} \mathrm{C}$ & 97.0 \\
\hline$t_{3}=t_{4}$ & $30.0 \quad{ }^{\circ} \mathrm{C}$ & $86.0 \quad{ }^{\circ} \mathrm{F}$ \\
\hline$t_{5}=t_{6}$ & $-14.5{ }^{\circ} \mathrm{C}$ & 5.9 \\
\hline$t_{7}$ & $-7.2 \quad{ }^{\circ} \mathrm{C}$ & 19.0 \\
\hline$t_{8}$ & $22.3 \quad{ }^{\circ} \mathrm{C}$ & 72.1 \\
\hline$t_{9}$ & $0.0 \quad{ }^{\circ} \mathrm{C}$ & 32.0 \\
\hline$t_{10}$ & $-22.2{ }^{\circ} \mathrm{C}$ & -8.0 \\
\hline$t_{11}$ & $-17.1{ }^{\circ} \mathrm{C}$ & 1.2 \\
\hline$t_{12}$ & $-15.5{ }^{\circ} \mathrm{C}$ & $4.1 \quad \circ \mathrm{F}$ \\
\hline Compressor power & $0.1259 \mathrm{~kW}$ & $0.1259 \mathrm{~kW}$ \\
\hline
\end{tabular}


resembles a distillation column in the process industries and would be capable of shifting Point 4 further to the left on Fig. 5-2 and the liquid further to the right. One result of this wider separation of concentrations would be that the high-temperature evaporator would operate at a higher temperature. Since this evaporator is now operating between $-14^{\circ} \mathrm{C}$ and $-7{ }^{\circ} \mathrm{C}\left(7{ }^{\circ} \mathrm{F}\right.$ and $19^{\circ} \mathrm{F}$ ), this higher temperature would be permissible. What is important for the energy requirement is that the freezer evaporator would shift to a lower temperature, or instead the suction pressure could be elevated to maintain the same temperatures and thus reduce the power required by the compressor.

The temperature of the liquid at Point 9 was arbitrarily fixed at $0{ }^{\circ} \mathrm{C}\left(32^{\circ} \mathrm{F}\right)$. A lower temperature at this point should be possible which would improve the performance further.

There is no assurance that the circuiting in the cycle shown in Fig. 5-1 is the most favorable. It may be more effective, for example, to perform the condensation in the low-temperature condenser using evaporating and even superheating refrigerant that flowe from the freezer evaporator.

The most compeliing reason for suggesting continued consideration of the separating cycle is a thermodynamic one. The cycle is capable of performing part of the refrigeration at the low temperature needed for the freezer and the other portion at a higher temperature for the fresh food compartment. Such a cycle would seem to have advantages even over the single-train system of Chapter 4 where a lower temperature than necessary prevails in the high-temperature evaporator. 


\section{CCNCLUSIONS AND RECOMMENDATIONS}

6-1. Go or no-go decision. The essential task of the contract on which this report is based is to arrive at a recommendation on whether to proceed further in the study of using refrigerant mixtures in domestic refrigerators or to abandon the effort. The basis of this recommendation was to be a critical review of the U.S. and foreign literature and independent cycle analyses. The results of this preliminary study are favorable enough to suggest proceeding. In a cycle analysis of a twoevaporator system using a 50 percent mixture of $R-12 / R-114$, the analysis indicated that the compressor power could be reduced by 12 percent and still perform the specified rate of refrigeration. The figures are based on a non-optimized cycle, so the saving could theoretically be higher.

6-2. Caution urged. While energy savings seem to be possible it is urged that only cautious claims be made so that any program that might follow would not be saddled with unrealistic expectations.

In the first place, it will not be possible simply to replace the $\mathrm{R}-12$ currently used in most refrigerators with a mixture of refrigerants. For example, the required compressor displacement rate must be altered. Also, two additional heat exchangers would have to be inserted in the cycle.

It is possible that the heat-transfer coefficlents will be less when a mixture of refrigerants is used. Haselden ${ }^{14}$ reported this to be the case, although this particular test of Haselden seems to be somewhat coarse. 
Oil problems will have to be investigated. Oil is quite soluble in R-12 at the low temperatures experienced in domestic refrigerators, however little information is reported about the characteristics of $0 i l$ and mixtures of refrigerants.

To take advantage of the changing temperature of the refrigerant in the evaporator and condenser, strict counterflow heat transfer between the refrigerant and external fluid should be sought. There will be physical problems in configuring the heat exchangers in domestic refrigerators to, achieve strict counterflow.

Another requirement for achieving good heat transfer is that the liquid and vapor remain in equilibrium during the evaporation and condensation processes. In two-phase flow there is always a tendency for the vapor and liquid to move at differing velocities-usually the vapor moves faster than the liquid. This "slip" should be avoided and possible methods of maintaining equilibrium are noted by Haselden. (1958).

6-3. Possible future steps. While the precautions mentioned above should be observed, they should not deter continued work, since almost any improvement in energy characteristics now comes only through struggle. The manufacturers of domestic refrigerators have a multitude of considerations that must be reviewed before they are able to introduce a new concept, even one that has some energy advantages. Among other considerations are the economic, manufacturing, and reliability ones. Probably the most useful next step is to continue expanding the knowledge base for refrigerant mixtures in order to permit the manufacturers to 


\section{$-55-$}

move more rapidly to their own unique and sometimes proprietary studies and decisions. The expansion of the knowledge base should include:

1. At least one experimental study with the facility designed to verify the analytical results presented in this and other reports. The system should conform to Fig. 4-1 and should be configured to achieve accurate measurements and not necessary be constricted by the space requirements of a refrigerator. The facility should have the capability of measuring thermal flow rates and heat-transfer coefficients in the heat exchangers. Varying mixtures of several combinations of refrigerants of refrigerants should be studied, and procedures should be developed to charge the system with precise mixtures.

2. Optimization studies of the cycle should be conducted, and these could start even before data are available from the experimental study, although no firm conclusions should be drawn until the information from the experimental study is factored into the optimization.

3. Various combinations of refrigerants should be investigated. The mixture used in this report combines a low-vapor-density refrigerant, $R-114$, with R-12. Another immediate possibility to consider is $\mathrm{R}-11$ which is a low-vapor-density refrigerant, or $\mathrm{R}-13$ which has higher vapor densities than R-12. The property equations of the mixtures should also be refined.

4. Refrigerators do not operate on a steady-state cycle, but are virturally always in a pump-down mode during which operation the evaporating temperatures are progressively dropping. The dynamic performance of the system using refrigerant mixtures should be explored both analytically and experimentally.

5. The separating cycle (described in Chapter 5) did not show favorable results in this initial study, but further analytical work would seem to be warranted before a decision to drop the idea or to proceed with experimental studies would be undertaken. 


\section{BIBLIOGRAPHY}

1. Agarwal, R. S. and C. P. Arora, Thermodynamic Properties of R-12/R-13 Mixtures, XIV International Congress of Refrigeration, Moscow, 1975.

2. Arora, C. P, Power Savings in Refrigerating Machines Using Mixed Refrigerants, XII Internationa Congress of Refrigeration, Madrid, 1967.

3. Arora, C. P., Low Temperatures in Refrigerating Machines with R-12 and R-13 Mixtures, XIII International Congress of Refirigeration, Washington, 1971.

4. Arora, C. P., A. K. Mittal, and A. K. Gupta, An Analysis of the Properties of Mixtures for Vapour Absorption Refrigeration, KIII Internatiumal Congress of Kefrigeration, Washington, 1971.

5. Bijlani, C. A., Pressure-Volume-Temperature Relationships of Binary Mixtures of Refrigerants, XIII International Congress of Refrigeration, Washington, 1971.

6. Bondarev, V. N., Investigation of a Heat Pump Operating on a Mixture of Refrigerants, Kholod. Tech., vol. 48, no. 11, pp. 13-16, 1971.

7. Bougard, J. and R. Jadot, Calculation of the Equilibrium Diagram for a Mixture of Liquid Refrigerants, XIV International Congress of Refrigeration, Moscow, 1975.

8. Carr, F., Power Savings in Process Refrigeration, Ind. \& Engr.

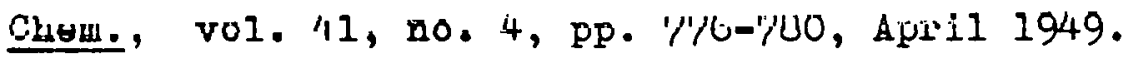

9. Certok, V. D., A. P. Kuznetzov, D. V. Goncarov, and V. S. Ovcaruk, The R-143/R-12 Refrigerant Mixture--a Working Substance for Small Refrigorating Unita, Luft-und Källelechnlk, vol. 10, no. 6, pp. 299-301, Dec. 1974.

10. Dmitriev, V. I., et. al., Comparative Tests of an Hermetic Compressor on Freon-12 and a Non-Azeotropic Mixture of Freon12 and 143, Kholod. Tech., vol. 31, no. 6, pp. 25-27, 1974.

11. Eiseman, B. J., Multicomponent Refrigerants, Proceedings of Commissions 3 and 6 of the International Institute of Refrig., Prague, Czech., Sept, 1965. 
12. Füderer, A. and W. Lessenich, Azeotropic and other Freonmixtures as Refrigerants, Kältetechnik, vol. 15, no. 8, pp. 235-239, August 1963.

13. Etherington, T. I., Patent No. 2,951,349 and 2,951,350, Variable Capacity Refrigeration.

14. Haselden, G. G. and I. Klimek, An Experimental Study of the Use of Mixed Refrigerants for Non-isothermal Refrigeration, Journ. of Refrig., vol. 1, no. 4, May/June 1958, pp. 87-89. Paper also reviewed in Modern Refrig., vol. 61, no. 722, p. 483, May 1958.

15. Heller, Z. E. and A. V. Egerov, Enthalpy-Concentration Diagrams for Mixtures of R-22/R-115 and R-13B1/R-12, Kholod, Tech., vol. 48, no. 11, p 62, 1971.

16. Kaiser, V, and C. Becdelievre, and D. Gilbourne, Mixed Refrigerant for Ethylene, Hydrocarbon Processing, vol. 55, no. 10, pp. 129-131, October 1976.

17. Kandlikar, S. G, C. A. Bijlani, and S. F. Sukhatme, Predicting the Properties of Mixtures of R-22 and R-12, Part I - Thermodynamic Properties, ASHRAE Trans., vol. 81, Part I, 1975, pp. 266-284.

18. Kazacki, G., Mixtures in Vapour Refrigerating Systems, Potravinarska a Chladici Technika, vol. 7, no. 5, pp 515.147 to $520.152,1976$.

19. Kazacki, G., Refrigerant Cycles Using non-Azeotropic Refrigerant Mixtures, Potravinarska a Chladici Technika, vol. 8, no. 5, pp. 500.132 to $503.135,1977$.

20. Klimenko, A. P., C. E. Krasnoky, and V. M. Kolesnik, The Utilization of the Generalized Starline-Han Equation for the Computerized Calculation of Thermodynamic Properties of Refrigerant Mixtures, Kholod. Tech., vol. 53, no. 8, pp. 26-28, 1976.

21. Klimek. L., The Generation of Cold with Mixtures of Refrigerants and its Industrial Application, Kältetechnik, vol. 11, no. 2, p. 55, Feb. 1959 .

22. Knudsen, H. J. H., and F. H. Larsson, Kefrigerat1ng Plunl with Single Stage Compression and a Non-Azeotrope Refrigerant Mixture, Kulde, vol. 25, no. 6, pp. 103-107, Dec. 1971. 
23. Kirebel, M., Iiquid-Vapor Phase Equilibria of the Binary System of R-22/R-12, K̈̈ltetechnik, vol. 19, no. 1, pp. 8-14, January 1967.

24. Kraus, W. E., G. Hackstein, and H. Wauer, Determination of the Thermodynamic Properties of Binary Mixtures of Halogenated Hydrocarbons, XIV International Congress of Refrigeration, Moscow, 1975.

25. Kruse, $H$, and $H$. Jakobs, The Significance of the Non-Azeotropic Binary Refrigerants when Used in Heat Pumps and Refrigeration Plants, Klima-Kälte Ingenieur, vol. 5, no. 7-8, pp. 253-260, July-August 1977.

26. Kruse, E., and H. Holdack-Janssen, Experimental Determination of the Thermodynamic Quantities of Non-azeotropic Binary Refriforants, Klimg-Kälte Thgenieur, vnl, 5, no. 9, pp. 307-312 Sept 1977.

27. Kuznetsov, A. P., V. D. Chertok, and V. C. Ovcharuk, on the Problems of Application of Mixtures of Freons in Small Refrigeration Machines, Kholod. Tech., vol. 52, no. 6, pp. 43-45, 1975.

28. Kuznetzov, A. P., I. V. Loc, and A. V. Egorov, EnthalpyConcentration Diagram of a Mixture of Freon-22 and 13B1, Kholod. Tech., vol. 50, no. 2, p 60, 1973.

29. Labochnik, A. E. and M. A. Ceonov, Patent on two Chamber Refrigerutor, Kholod. Tech., vol. 52, no. 8, p. 51, 1975.

30. Löffler, H. J., Some Properties of the Binary System Frenn-12/ Freon-22 and the Tertiary System of Freon-12/Freon-22/Mineral 1 Oil, Kältetechnik, vol. 12, no. 9, pp. 256-260, Sept. 1960.

31. Lorenz, A., On the Utilization of Binary Refrigerant Mixtures in Compression Refrigeration Systems, Luft-und Rältetechnik, vol. 9, no. 6, pp. 296-301, Dec. 1973.

32. Lorenz, A., Investigations of the Use of Non-azeotropic Refrigerant M1xture of $k-12 / R-11$ in Vapor Compression Systems, Luft und Kultetechnik, vo1. 11, no. 1, pp. 33-37, 1975.

33. Lorenz, A. and K. Meutzner, On Application of Non-Azeotropic Two-Component Refrigerants in Domestic Refrigerators and Home Freezers, XIV International Congress of Refrigerstion, Moscow, 1975. 
34. Makorov, V. N., Thermodynamic Properties of Mixtures of Freon-12 and 13 at Supercritical Pressures and Temperatures of Freon-13, by V. N. Makorov, Kholod. Tech., vol. 54, no. 7, 1977, pp. 29-32.

35. Mcharness, R. C. and D. D. Chapman, Refrigerating Capacity and Performance Data for Various Refrigerants, Azeotropes and

: Mixtures, ASHRAE Trans,, vol. 67, pp. 441-464, 1961.

36. Neilson, E. F. and D. White, The Heat of Vaporization and Solution of a Binary Mixture of Fluorocarbons, J. Phys. Chem., vol. 63, no. 9, pp. 1363-5, Sept. 1959.

37. Saluja, S. N., Use of Mixed Refrigerants in Vapour Compression Refrigeration Machines, Refrig. and Air Cond., vol. 81, Part I Jan. 1978, pp. 27-34; Part II, Feb. 1978, pp. 32-35; and Part III, Mar. 1978, pp. 80-83.

38. Schwind, H., Application of Binary Refrigerant Mixtures and their Presentation in the Enthalpy-Pressure Diagram, Kältetechnik, vol. 14, no. 4, April 1962, pp. 98-105.

39. Smirnov, G. F., Calculation of Heat-and Mass-Transfer During Condenstion of Binary Mixtures on Finned Surfaces, Kholod. Tech., no. 12, pp. 31-33, 1975.

40. Spauschus, H. O., Vapor Pressures of Mixtures of Refrigerants 12 and 22, ASHRAE Journal, vol. 4, no. 9, pp. 49-51, 123, Sept. 1962.

41. Swenson, I. K and J. I. Peterson, The Pritchard Mixed Refrigerant Process, Third Int. Conf. on LNG, Washington, DC, Sept. 24-28, 1972, Session II, Paper 1.

42. Tschaikovsky, V. F. and A. P. Kuznetsov, Utilization of Refrigerant Mixtures in Refrigerating Compression Machines, XI Interrational Congress of Refrigeration, Munich, 1963.

43. Tschaikovsky, V. F. and A. P. Kuznetzov, Investigation of Mixtures of Refrigerants in Compression Refrigeration Machines, Kholod. Tech., vol. 40, no. 1, pp. 9-11, 1963.

44. Tschaikovsky, V. N., A. P. Kuznetsov, and N. I. Vodyanitskaya, Investigation of Refrigerating Machines Operating with Mixtures of Refrigerants, XII International Congress of Refrigeration, Madrid, 1967. 
45. Tschaikovsky, V. F., G. F. Smirnov, and R. A. Domansky, Investigations of the Process of Condensing Two-Component Mixtures of Freon-12 and 22, Kholod. Tech., vol. 49, no. 3, pp. 41-42, 1972.

46. Tschaikovsky, V. F., A. P. Kuznetzov, V. D. Chertok, and U. A. Bacutinski, Experimental Investigation of a Two-Stage Refrigeration Machines Operating on a Mixture of Freon-12 and Freon-23. Kholod. Tech., no. 4, vol. 49, pp. 7-9, 1972.

47. Tschaikovsky, V. F., R. A. Baktozin, E. E. Pukanov, and B. V. Puchkob, Investigation of the Heat- and Mass-Transfer by Condensation of Mixtures of Freon-12 and -22 on Horizontal Finned Tubes, Kholod. Tech., vol. 50, no. 2, pp. 24-28, 1973.

48. Tschaikovsky, V. F., R. A. Domansky, and B. V. Puchkob, Caleulation of the Heat- and Passatrangfer Aleu fur Cundensation of R-12/R-22 Mixtures on Horizontal Tubes, Kholod. Tech., vol. 53 no. 8, pp. 24-26, 1976.

49. York-Shipley British Patent 778483, Modern Refrigeration, vol. 60, no. 713, pp. 342-348, August 1957. 
APPENDIX A. SYNOPSIS OF LITERATURE

1. Agarwal (1975). Gives some property data for $R-12 / R-13$. Recommends Redlich-Kwong equation to express the non-ideality of the vapor phase.

2. Arora (1967). Analytical and experimental study of R-22/R-114 system. Experiments indicate maximum improvement of COP of 20 percent using 10 percent composition of $R-114$.

3. Arora (1971). Experiments with $R-12 / R-13$ show improvement of COP with peak at 30 percent $R-13$ in $R-12$.

4. Arora (1971). Paper directed toward mixtures of refrigerants applicable to absorption machines.

5. Bijlani (1971). Concentrates only on azeotropic mixtures.

6. Bondarev (1971). Applications of mixtures to heat pumps. Found an improvement in both capacity and COP with $R-143 / R-142 \mathrm{mix}-$ ture in comparison to pure $R-12$.

7. Bougard (1975). Uses activity coefficients to compute intermolecular interactions in determining $\mathrm{p}-\mathrm{x}-\mathrm{T}$ and $\mathrm{h}-\mathrm{x}-\mathrm{T}$ relations.

8. Carr (1949). Theoretical study using three-substance mixture of ethane, propane, and butane. With the mixture the required power would be 71 percent of that needed if ammonia were used.

9. Certok (1974). Exploration of adding R-12 to R-143 to improve the oil solubility characteristics of $\mathrm{R}-143$.

10. Dmitriev (1974): Reports tests on R-143/R-12 mixture. Directed toward using $R-143$ as predomant component. Advantage of R-143 is that it can absorb more water than R-12.

11. Eiseman (1965). Emphasis of paper is on azeotropes, but does make some useful comments about non-azeotropes (which combinations behave as perfect mixtures).

12. Füderer (1963). Almost exclusively devoted to azeotropes.

13. Etherington. Uses mixtures to vary the refrigerating capacity of a refrigeration system.

14. Haselden (1958). Analytical and experimental study of mixtures using butane and propane. Showed 15 percent reduction in power for a given refrigeration rate. Heat transfer coefficients with mixture seem lower. 
15. Heller (1971). Enthalpy-concentration diagrams for saturated liquid and sáturated vapor. Found $R-13 B I / R-12$ behaved as perfect mixture.

16. Kaiser (1976). Ten percent less power consumed when using a mixture of methane, ethylene, and propane to cool an ethylene stream from -30 to $-90^{\circ} \mathrm{C}$.

17. Kandlikar (1975). Complete thermodynamic data for $R-12 / R-22$.

18. Kazacki (1976). Shows $\mathrm{T}-\mathrm{x}-\mathrm{p}$ diagram for $\mathrm{R}-12 / \mathrm{R}-13$. Cites a report written by author that gives properties of a variety of combinations of mixtures.

19. Kazacki (1977). Discusses a cycle having two evaporators operating at different temperature levels served by refrigerants separated into high-and low-boiling point fractions.

20. Klimenko (1976). Application of starling-Han correction to refrigerant mixtures gives an appreciable improvement in accuracy.

21. Klimek (1959). Review of paper written with Haselden (14).

22. Knudsen (1971). Application directed toward achieving low temperatures with a moderate compression ratio.

23. Kriebel (1967). Concentrates on $R-12 / R-22$. Seems to give a good review of equations. Provides references to activity coefficient data which might be useful.

24. Kraus (1975). States that ideal mixture relationships apply to $\mathrm{R}-143 / \mathrm{R}-142, \mathrm{R}-12 / \mathrm{R}-11, \mathrm{R}-12 / \mathrm{R}-114$, and $\overline{\mathrm{R}}-22 / \mathrm{R}-2 \mathrm{i}$.

2b. Kruse (1977). Directed toward the possible use of mixtures in heat pumps.

26. Kruse (1977). Continuation of heat pump work from (25) and concentrates in $R=1 \varepsilon / R-11$ mlxlure. Describes laburatory equipment to verify p-v-t relations of this mixture.

27. Kuznetsov (1975). Cites work indicating that energy characteristics of domestic refrigerators are improved by a $R-12 / R-143$ mixture over that experienced with pure $R=12$.

28. Kuznetsov (1973). Presents graph computed through the use of activity coefficients for the enthalpies of $R-22 / R-13 B I$. 
29. Labochnik (1975). Two evaporator domestic refrigerator using a separating cycle with the low-boiling point fraction serving the freezing evaporator.

30. Löffler (1960). Directs paper toward the precise concentration at which $\mathrm{R}-12$ and $\mathrm{R}-22$ form an azeotropic mixture.

31. Lorenz (1973). Reviewed 30 mixtures to develop an expression relating the maximum temperature difference between saturated liquid and saturated vapor as a function of the difference in boiling points.

32. Lorenz (1975). Experimental tests of single-evaporator refrigerator using $R-12 / R-11$ showing improved $C O P$ with an 85 percent fraction of $R-12$.

33. Lorenz (1975). Two-evoporator domestic refrigerator using a mixture of $R-22 / R-11$ and showing that the power savings were as high as 20 percent with a 50-50 mixture in comparison to pure $\mathrm{R}-12$.

34. Makorov (1977). Presents $\mathrm{p}-\dot{\mathrm{x}}-\mathrm{T}$ and $\mathrm{h}-\mathrm{x}-\mathrm{T}$ diagrams of a $30-$ percent mixture of $R-13 / R-12$.

35. MeHarness (1961). Experimental tests of $R-22 / R-12, R-13 B / R-12$, and $R-13 B / R-22$ mixtures and found improvements in COP with the mixtures in comparison to pure refrigerants.

36. Neilson (1959). Describes a calorimeter for measuring heats of vaporization. Ran tests on $R-12 / R-22$ and found that proportioning the latent heats according to the mass fraction prevailing in the mixture is a good first approximation.

37. Saluja (1978). Cycle calculations using $R-22 / R-114$ show 15 percent improvement in COP.

38. Schwind (1962). Use of refrigerant mixtures to provide capacity adjustment in a refrigeration system that has a constant compressor displacement.

39. Smirnor (1975). Shows a 4 percent difference in condensing coefficient with two different concentrations of R-12 in an $\mathrm{R}-12 / \mathrm{R}-22$ mixture. 
40. Spauschus (1962). Pulls together some of the previously published data on the vapor pressures of $R-12 / R-22$.

41. Swenson (1972). Uses nitrogen with a spectrum of hydrocarbons. as the refrigerant in an ING system. Firm has four in operation.

42. Tschaikovsky (1963). Experimental tests using 30 percent $R-13$ in $\mathrm{R}-12 / \mathrm{R}-13$. Oil characteristics satisfactory down as low as $-60{ }^{\circ} \mathrm{C}$.

43. Tschaikovsky (1963). Uses $R-12 / R-22$ mixture. In process of tests some condensing heat-transfer data were accumulated.

44. Tschaikovsky (1967). A two-compressor system applied to a separating condenser cycle to achieve extremely low temperatures.

45. Tschaikovsky (1972). Shows drop in condensing coefficient in mixture of $R-12 / R-22$ at about 20 percent $R-12$. The drop is most noticeable whon experiencing high heat fluxes.

46. Tschaikovsky (1972). Uses $\mathrm{R}-12 / \mathrm{R}-23$ in the compression cycle using two compressors. Shows an 1mprovement in COP with the R-12/R-23 mixture over pure $\mathrm{R}-22$ with an evaporating temperature of $-70^{\circ} \mathrm{C}$.

47. Tschaikovsky (1973). The mixture of $R-12 / R-22$ has a lower heat transfer coefficient than either constituent, although the degradation is least at high $\Delta t^{\prime} s$.

48. Tschaikovsky (1976). Shows how to use data of (47) to compute condenser area.

49. York-Shipley (1957). Similar to Schwind (38) in that through the use of refrigerant mixtures it is possible to vary the refrigerating capacity of a system using a constant displacement compressor. 
APPENDIX B. EQUATIONS SUBROUTINE FOR COMPUTER PROGRAM USED IN CHRPTER 5 .

Equations are of the form

$$
R(i)=f(V(j), V(k))
$$

where the equation is satisfied when $R(i)$ is driven to zero. The V( )'s refer to variables as listed below.

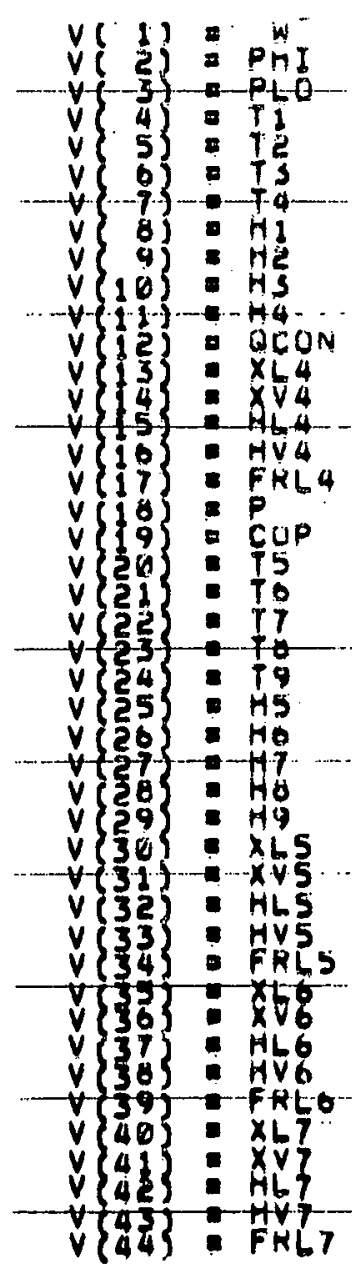




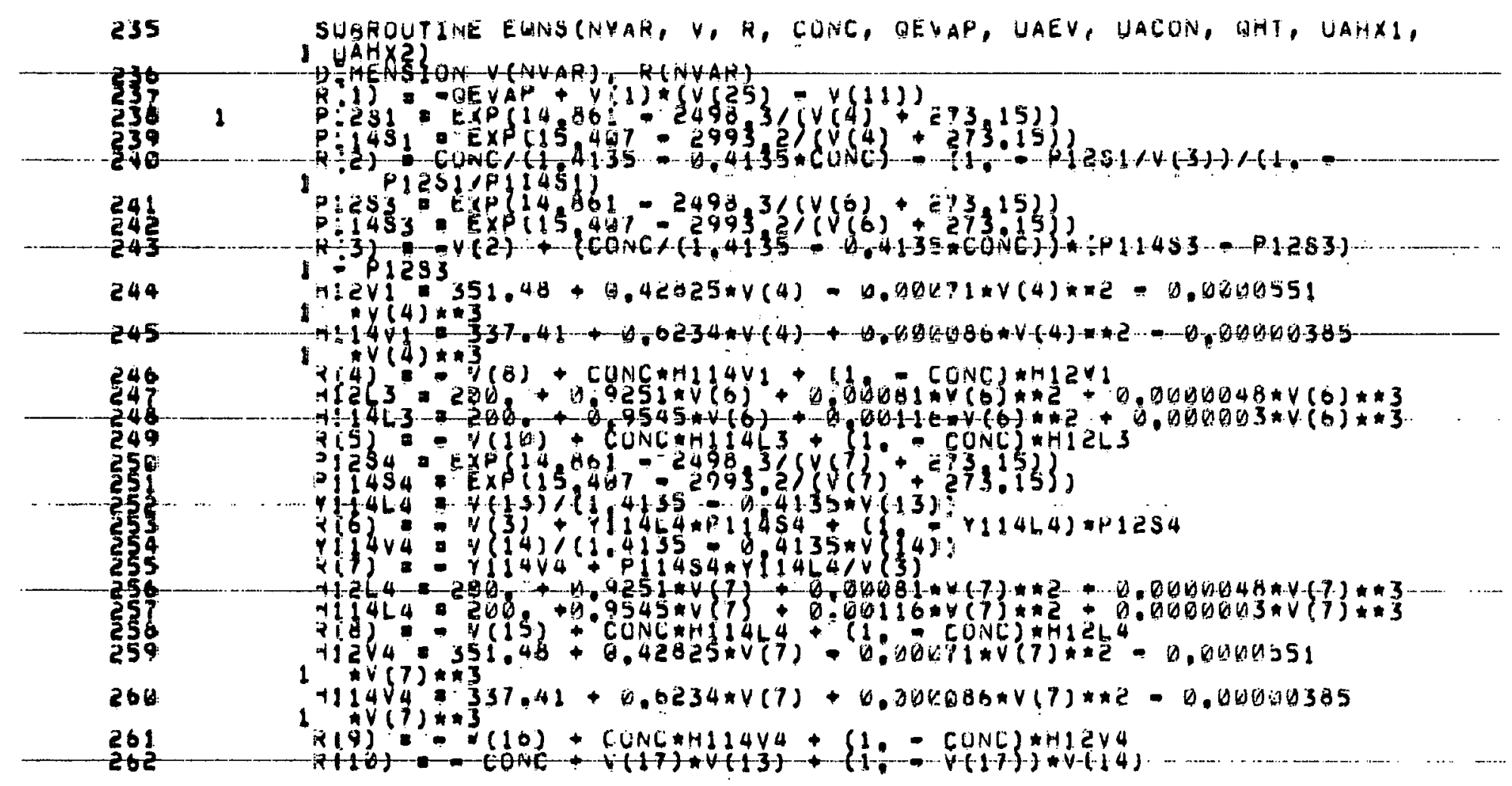




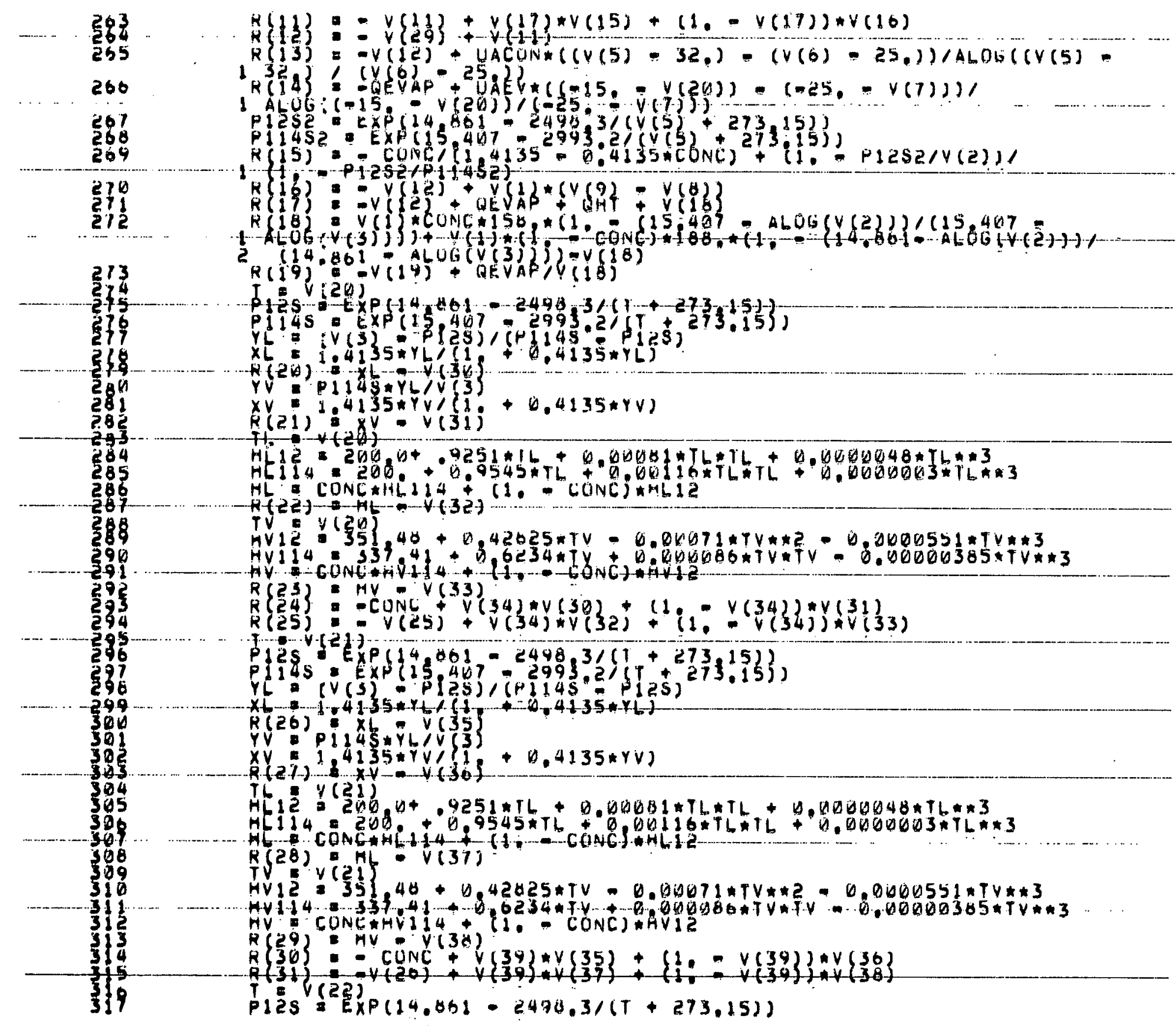




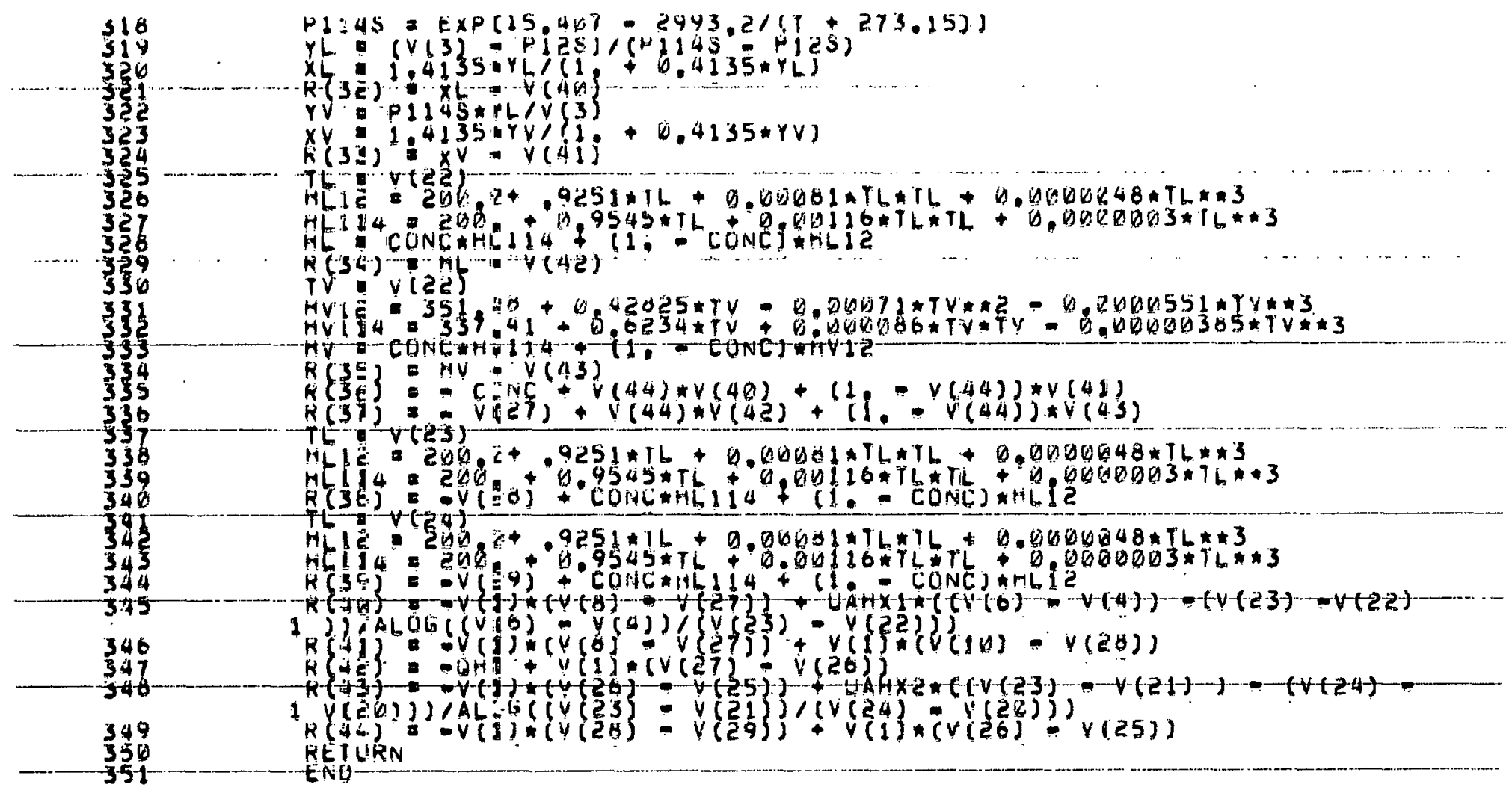

